\title{
Recent synthetic applications of the dealkoxycarbonylation reaction. Part 1. Dealkoxycarbonylations of malonate esters
}

\author{
A. Paul Krapcho \\ Department of Chemistry, University of Vermont, Burlington, VT 05405 USA \\ E-mail: A.Paul.Krapcho@uvm.edu
}

\begin{abstract}
The purpose of this review is to update (publications from 1981 to mid 2006) the synthetic applications of dealkoxycarbonylations of malonate esters, $\beta$-keto esters (and related esters with $\alpha$-substituted electron-withdrawing functionalities) induced by heating with water or with water in the presence of salts (such as $\mathrm{NaCN}, \mathrm{NaCl}$ or $\mathrm{LiCl}$ ) in dipolar aprotic solvents. The presentation will be divided in two parts. In Part 1, discussion will focus on the dealkoxycarbonylations of malonate esters. Part 2 (to follow as a separate paper) will deal with the dealkoxycarbonylations of $\beta$-keto esters and $\alpha$-cyano esters (and related analogues).
\end{abstract}

Keywords: Dealkoxycarbonylations, Krapcho, decarbalkoxylations, malonate esters

\section{Contents}

1. Introduction

2. Mechanistic Considerations

3. Esters

3.1. From monosubstituted malonate esters

3.1.1. Water alone

3.1.2. Water-salts

3.1.2.1. From alkyl, alkenyl, alkynyl and allenic malonate esters

3.1.2.2. From 2-cycloalkyl and 2-cycloalkenyl malonate esters

3.1.2.3. From aryl substituted malonate esters

3.1.2.4. From 2-heterocyclic substituted malonate esters

4. Diesters

4.1. From substrates with two malonate ester functionalities

5. Demethoxycarbonylation-Rearrangement

6. Aryl Methyl Substituted Benzenes

6.1. From bis-dealkoxycarbonylations 
7. Esters

7.1. From disubstituted malonate esters

7.1.2 Bis-alkyl

7.1.3. Alkyl-benzylic

7.1.4. Dimethylamino-benzyl

7.1.5. Indanyl-carboethoxymethylene

7.1.6. Benzocyclobutane substituted cyclopentanes

7.1.7. Alkyl-heterocyclic

7.1.8. Cycloalkyl-1,1,-dicarboxylic esters

7.1.9. Alkyl-alkenyl

7.1.10. Alkenyl-bromoalkyl

7.1.11. Alkenyl-fluoro

7.1.12. Alkenyl-alkenyl

7.1.13. Alkynyl-alkynyl

7.1.14. Alkenyl-alkynyl

7.1.15. Alkenyl-heterocyclic

7.1.16. Ethynyl-heterocyclic

7.1.17. Cyclopropyl-dichloroalkenyl

7.1.18. Carbocylic-1,1-dicarboxylic acid diesters

7.1.19. Heterocyclic-1,1,-dicarboxylic acid diesters

7.1.20. 2-Acylamino substituted analogues

7.1.21. Aryl-heteroaryl

7.1.22. Bi-cyclic malonate ester

7.1.23. Substituted $\alpha$-difluorobromomethyl malonate

7.1.24. Trimethyl methanecarboxylate

7.1.25. Dealkoxycarbonylation-eliminations

7.1.26. Substituted heterocyclic system

7.1.27. Cinnamic esters: from arylmethylene-propanedioic acid dimethyl esters

8. Conclusions

9. References

\section{Introduction}

Activated esters, which include such substrates as malonates, $\beta$-ketoesters and $\alpha$-cyanoesters, are of considerable importance in organic synthesis. We have reported in a number a publications that these substrates (and other activated analogues) undergo dealkoxycarbonylations on being heated in dipolar aprotic solvents (such as DMSO or DMF) in the presence of water, or in some substrates with water in the presence of added salts (such as $\mathrm{NaCN}, \mathrm{NaCl}$ or $\mathrm{LiCl}$ ) to yield the corresponding esters, ketones and nitriles. This procedure is facile, avoids harsh acidic and 
alkaline conditions and tolerates many protecting groups. In addition, this methodology is much more convenient than the classical procedures for accomplishing these transformations.

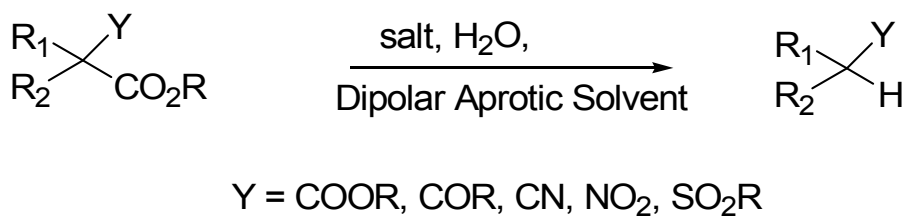

This overall process is a formal loss of $\mathrm{CO}_{2} \mathrm{R}$ and protonation of the intermediate carbanion ( a dealkoxycarbonylation or a decarbalkoxylation).

Two previous reviews of the synthetic applications of this methodology and mechanistic considerations were published in 1982. ${ }^{1,2}$ Subsequently, this procedure has been referred to as the Krapcho reaction or the Krapcho dealkoxycarbonylation. ${ }^{3-8}$

A recent check of the Science Citation Index Expanded (1982 to mid 2006) indicated about 1100 citations to the papers published by the Krapcho group dealing with the dealkoxycarbonylation procedure. The goal of the present review is to update the literature on the more recent strategies of this methodology in synthesis. Because of the large numbers of published papers, the author is going to be somewhat selective in the illustrative synthetic examples chosen from the literature.

\section{Mechanistic Considerations}

Mechanistically, the dealkoxycarbonylation constitutes an ester hydrolysis followed by decarboxylation and subsequent protonation of a carbanion species or a concerted dealkylative decarboxylation followed by protonation of the incipient carbanion. The mechanism is clearly dependent on whether the substrate is heated in the dipolar aprotic solvent with water or water in the presence of salts. Some mechanism details have been discussed in the prior review. ${ }^{1}$ The overall mechanistic pathway is dependent on the substrate structure and the reaction conditions. $^{3-9}$

The cleavages of the aziridinyl malonate $\mathbf{1}$ have been studied using $\mathrm{NaCN}$ or $\mathrm{NaCl}$ in aqueous DMSO. In the case of $\mathrm{NaCN}$ in $\mathrm{DMSO}$ and water $\left(110^{\circ} \mathrm{C}, 6 \mathrm{~h}\right)$, the product was 2 $(49 \%)$. In the use of DMSO, $\mathrm{NaCl}$ and water $\left(150^{\circ} \mathrm{C}, 2 \mathrm{~h}\right)$, the product was $3(31 \%)$. A mechanistic rationalization possibly involving $\mathrm{N}$-participation is proposed. ${ }^{10}$

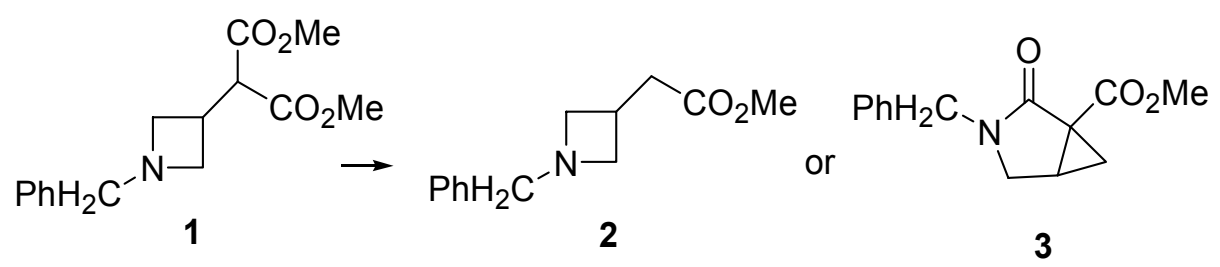




\section{Esters}

\subsection{From mono substituted malonate esters}

\subsubsection{Water alone}

As noted in our previous review, ${ }^{1}$ the dealkoxycarbonylations of a number of mono substituted malonates can be accomplished by heating in a dipolar aprotic solvent such as DMF or DMSO with added water to yield the corresponding mono esters. Additional examples of this methodology continue to be reported.

The diester 4-(R) on heating in DMSO and water $\left(170^{\circ} \mathrm{C}, 13 \mathrm{~h}\right)$ yielded the monoester 5-(S) $(80 \%){ }^{11}$

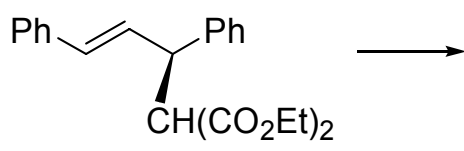

4-(R)<smiles>CCOC(=O)C[C@@H](/C=C/c1ccccc1)c1ccccc1</smiles>

5-(S)

The keto diester (+)-6 on being heated in wet DMSO $\left(190^{\circ} \mathrm{C}, 5 \mathrm{~h}\right)$ underwent decarbomethoxylation to afford the keto ester $(+)-7(60 \%)$. In a similar manner the (-) diester enantiomer could be converted into the (-) ester. ${ }^{12}$

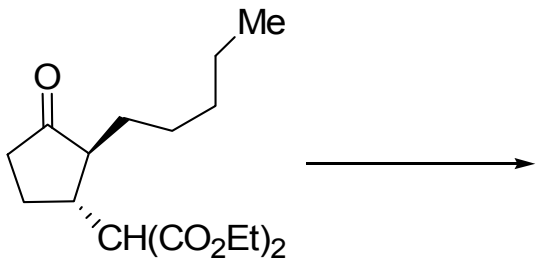

$(+)-6$

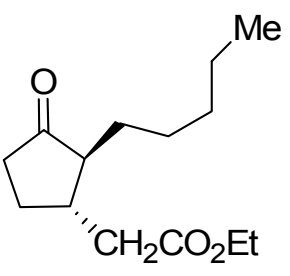

$(+)-7$

The dealkoxycarbonylations of malonic esters have been performed using microwave irradiation under solvent free solid-liquid phase transfer conditions. For example treatment of 8 with $\mathrm{LiBr}$ and water, $\mathrm{LiBr}$, water and a PTC agent such as Aliquat 336, or $\mathrm{NBu}_{4} \mathrm{Br}$ and water under microwave conditions $(10 \mathrm{~min}$ at $30 \mathrm{~W})$ led to the deethoxycarbonylated product 9 in $70 \%$, $85 \%$ and $96 \%$ yields, respectively. ${ }^{13 a, b}$<smiles>CCOC(=O)C(C)C([18OH])C(=O)OCC</smiles>

The dealkoxycarbonylations of several mono-substituted malonates have been shown to proceed in wet DMF under microwave conditions. For example, the conversion of diester $\mathbf{1 0}$ to ester $11(84 \%)$ was accomplished at $160^{\circ} \mathrm{C}$ for $20 \mathrm{~min}^{14}$ 


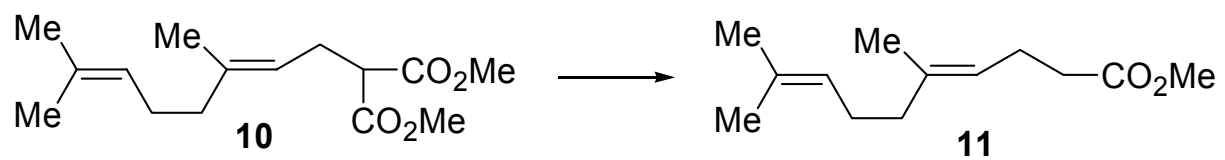

The deethoxycarbonylation of $\mathbf{1 2}$ in HMPA and water $\left(120^{\circ} \mathrm{C}, 2.5 \mathrm{~h}\right)$ afforded $\mathbf{1 3}(94 \%){ }^{15}$

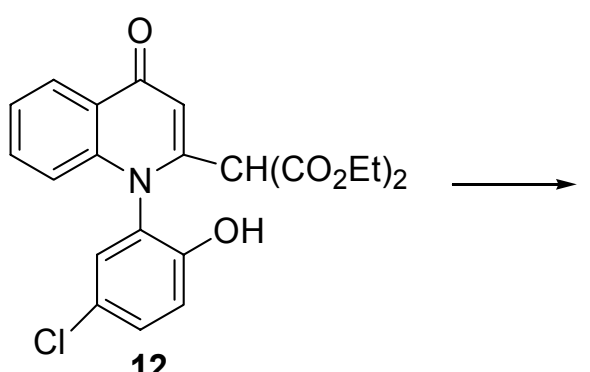

12<smiles>CCOC(=O)Cc1cc(=O)c2ccccc2n1-c1cc(Cl)ccc1O</smiles>

13

\subsubsection{Water - salts}

The dealkoxycarbonylations of a wide variety of substituted malonate esters have been reported using DMSO or DMF, water and salts such as $\mathrm{NaCl}, \mathrm{LiCl}$ and $\mathrm{NaCN}$. Numerous protective groups in the substrate are tolerated under the reaction conditions. The reactions are roughly classified according to the structure of the substituents.

3.1.2.1. From alkyl, alkenyl, alkynyl and allenic malonate esters. The diester 14-(S) on treatment with $\mathrm{DMSO}, \mathrm{NaCl}$ and water $\left(155^{\circ} \mathrm{C}, 48 \mathrm{~h}\right)$ led to ester $15-(\mathrm{S})(89 \%)$, along with a small amount $(6 \%)$ of the corresponding acid. ${ }^{16}$
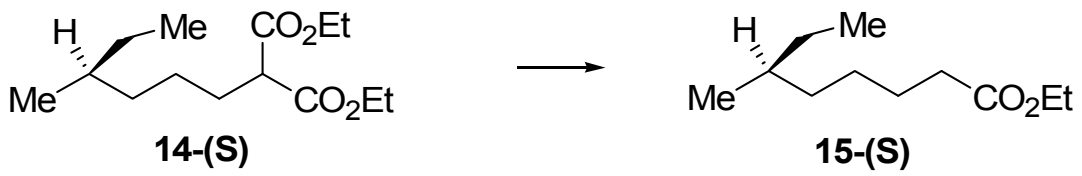

To ascertain the isotope effect on pheromonal activity, the aggregation pheromone of the red flour beetle, deuterated analogues of 4,8-dimethyldecanal were synthesized. Treatment of 16 with DMSO, $\mathrm{LiCl}$ and water (reflux, $48 \mathrm{~h}$ ) led to the deuterated analogue 17 (53\%) which was subsequently transformed into 4-trideuteriomethyl-8-methyldecanal . ${ }^{17}$

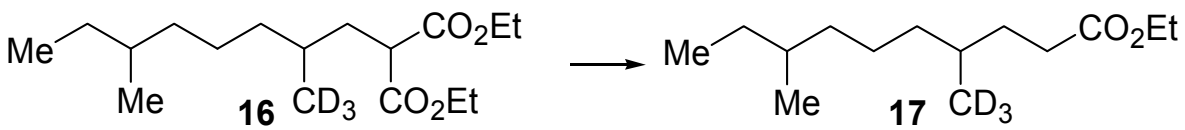

The deethoxycarbonylations of carbon-14 labelled malonate esters 18a and $\mathbf{1 8 b}$ can be readily accomplished on treatment with $\mathrm{LiBr}$, Aliquat 336 and water under microwave irradiation $\left(200^{\circ} \mathrm{C}, 10 \mathrm{~min}\right)$ to afford $19 \mathbf{a}$ and $\mathbf{1 9 b}$, respectively. The synthesis of $19 \mathbf{a}(60 \%)$ and 19b $(57 \%)$ could also be accomplished in a one-pot route based on a solvent -free alkylation of 
the carbon-14 labeled diethyl malonate followed by a microwave activated deethoxycarbonylation in the presence of $\mathrm{LiBr}$, Aliquat 336 and water. ${ }^{18}$

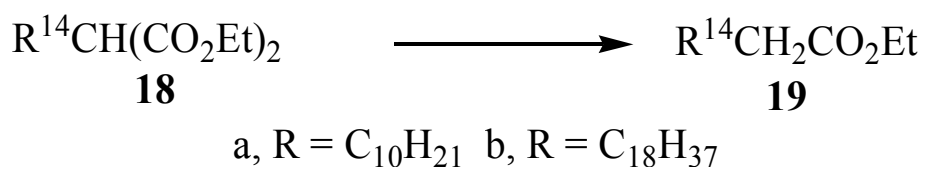

Treatment of racemic $20(51.3 \mathrm{~kg})$ with $\mathrm{DMSO}, \mathrm{NaCl}$ and water $\left(137-148^{\circ} \mathrm{C}, 8.5 \mathrm{~h}\right)$ led to the $\beta$-cyano ester $21(86 \%)$. This substrate was evaluated as an intermediate in the synthesis of the anticonvulsant (S)-3(aminomethyl)-5-methylhexanoic acid. ${ }^{19}$<smiles>CCOC(=O)CC(C#N)CC(C)C</smiles>

A number of $\mathrm{C}$-silylated malonate esters have been demethoxycarbonylated using DMSO, $\mathrm{NaCl}$ and water ( reflux, $24 \mathrm{~h}$ ). A typical example is the conversion of a mixture of $22[\beta-\mathrm{Me}$ $(85 \%)$ and $\alpha-\mathrm{Me}(15 \%)]$ into 23 [ $\beta-\mathrm{Me}(85 \%)$ and $\alpha-\mathrm{Me}(15 \%)]$ in an overall $81 \%$ yield. ${ }^{20}$
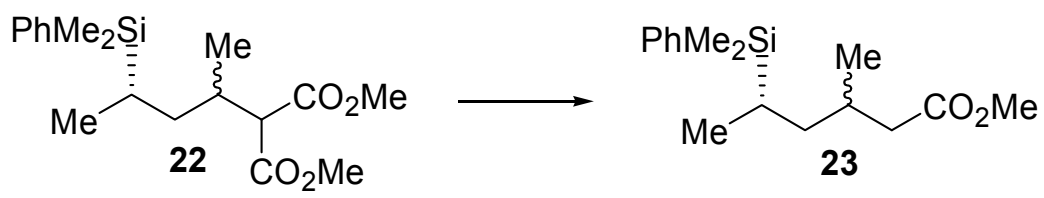

The demethoxycarbonylation of $\mathbf{2 4} \cdot \mathbf{H C l}$ with $\mathrm{DMSO}, \mathrm{NaCl}$ and water (reflux, $2 \mathrm{~h}$ ) led to (S)-3-aminobutyrate (25) [86\%>95\% ee], which was readily converted into the simple chiral $\beta$ $\operatorname{lactam}(95 \%$ ee $){ }^{21}$

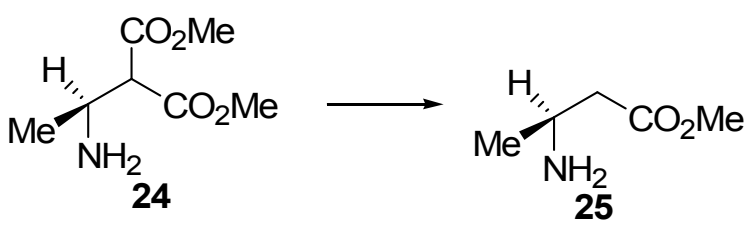

Racemic 26 was converted into racemic 27 on treatment with tetrabutyl ammonium acetate in dry DMSO $\left(100^{\circ} \mathrm{C}\right.$, heat). This procedure gave better yields than heating in DMSO with $\mathrm{NaCl}$ and water. ${ }^{22}$

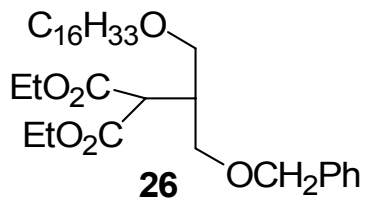

26
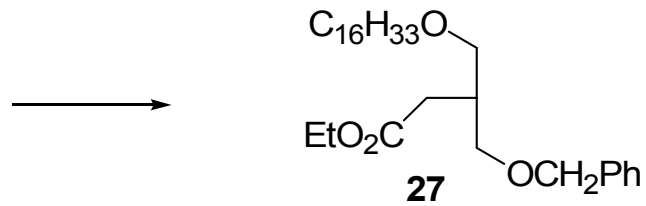
The Michael adducts 28 upon heating in DMSO, $\mathrm{NaCl}$ and water $\left(130^{\circ} \mathrm{C}, 24 \mathrm{~h}\right)$ led to the (3S)-substituted tert-butyl butanethioates 29, chiral differentiated glutarate esters. ${ }^{23}$

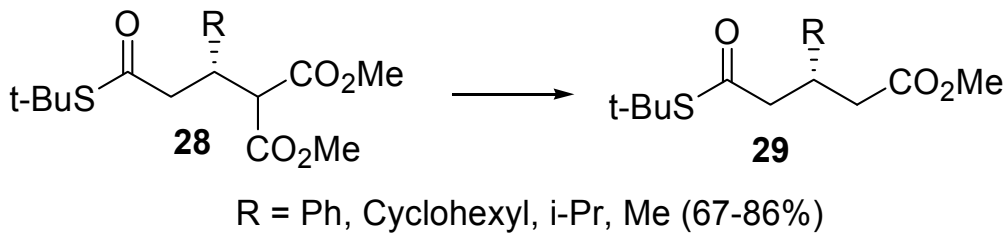

Treatment of 30 (40\%ee) with DMSO and water $\left(150^{\circ} \mathrm{C}, 20 \mathrm{~h}\right)$ led to the thio ester $31(65 \%$, $64 \%$ ee). This could be converted into chiral (R)-methyl 3-(benzoylamino)butanoate. ${ }^{24}$

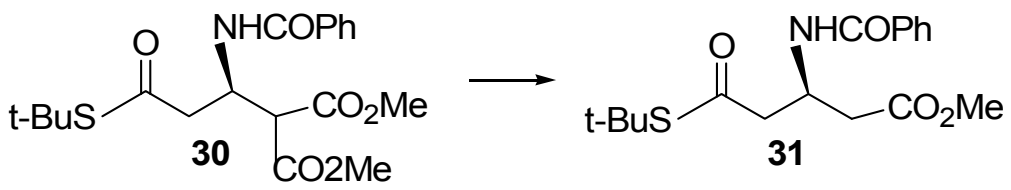

Treatment of 32 with DMSO, $\mathrm{LiCl}$ and water (reflux, 5 h) yielded $33(95 \%){ }^{25}$

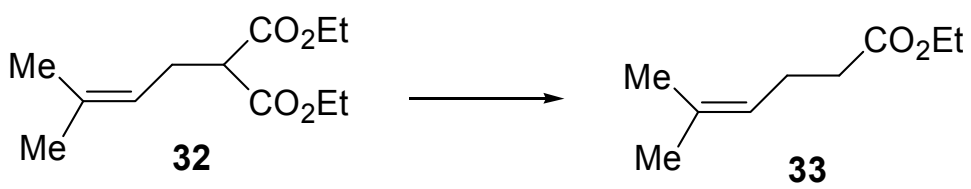

The bromo allyl diester 34 on heating in DMSO, $\mathrm{NaCl}$ and water (reflux, $8 \mathrm{~h}$ ) led to the bromo monoester $35(67 \%)$. ${ }^{26}$<smiles>C=C(Br)CCC(=O)OCC</smiles>

The decarbomethoxylation of 36 with $\mathrm{DMSO}, \mathrm{LiCl}$ and water $\left(130-160^{\circ} \mathrm{C}, 6 \mathrm{~h}\right)$ led to the keto ester $37(65 \%){ }^{27}$<smiles>CC(=O)CC/C(C)=C/CC(C(C)=O)C(C)=O</smiles>

The demethoxycarbonylation of optically active $\mathbf{3 8}$ with $\mathrm{NaCN}$ and LiI in DMF $\left(128^{\circ} \mathrm{C}, 16\right.$ h) led to optically active $39(64 \%){ }^{28 a, b}$ 


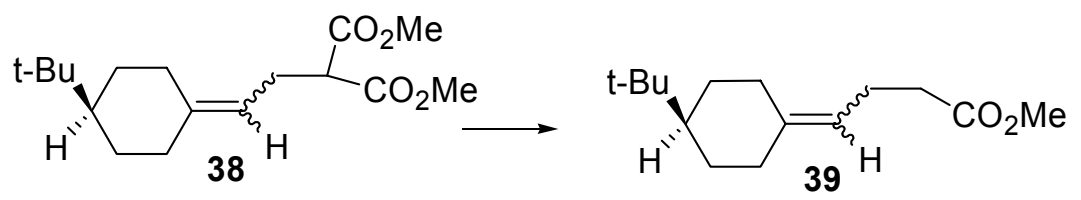

The deethoxycarbonylation of $\mathbf{4 0}$ with DMSO, $\mathrm{NaCl}$ and water $\left(170-180^{\circ} \mathrm{C}, 8 \mathrm{~h}\right)$ led to $\mathbf{4 1}$ $(60 \%)$, which was used in the synthesis of the sex pheromone of the rice green caterpillar. ${ }^{29}$

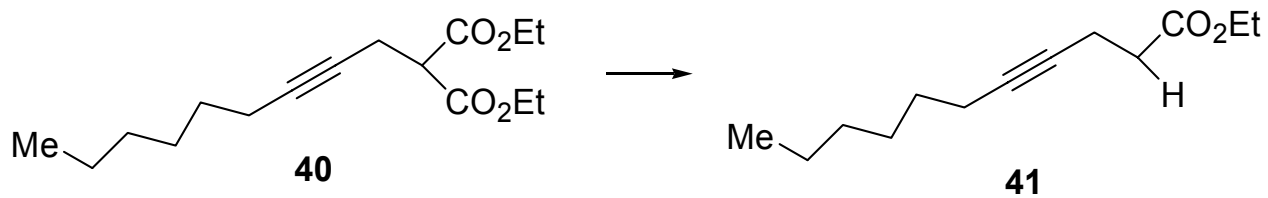

Treatment of (R)-42 with a mixture of $\mathrm{LiI}$ and $\mathrm{NaCN}$ in $\mathrm{DMF}\left(120^{\circ} \mathrm{C}, 6 \mathrm{~h}\right)$ or $\mathrm{NaCl}$ and water in DMSO $\left(130^{\circ} \mathrm{C}, 8 \mathrm{~h}\right)$ led to demethoxycarbonylation with partial racemization of the allenic axial chirality to afford (R)-43 $\left(82 \%, 54 \%\right.$ ee) or (R)-43 $(35 \%, 69 \%$ ee $)$, respectively. ${ }^{30}$

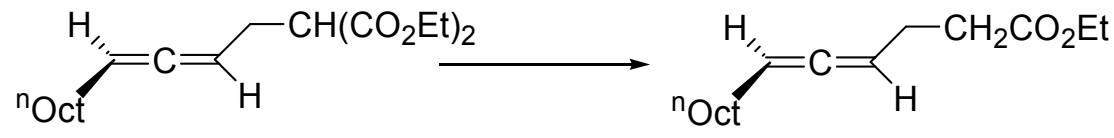
(R)-42 (77\%ee)
(R)-43

The deethoxycarbonylation of $\mathbf{4 4}$ with $\mathrm{DMSO}$ and $\mathrm{NaCN}\left(160^{\circ} \mathrm{C}, 4 \mathrm{~h}\right)$ afforded 45 $(40 \%){ }^{31}$<smiles>C=C=C(C)C(C(C)C)C(C(=O)OCC)C(=O)OCC</smiles><smiles>C=C=C(C)C(CC(=O)OCC)C(C)C</smiles>

3.1.2.2. From 2-cycloalkyl and 2-cycloalkenyl malonic esters. The racemic starting material 46 on treatment with $\mathrm{DMSO}, \mathrm{NaCl}$, water $\left(160^{\circ} \mathrm{C}, 36 \mathrm{~h}\right)$ yielded $47(40 \%){ }^{32}$

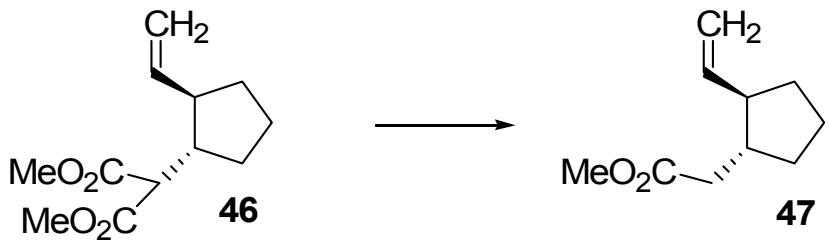

Treatment of (+) 48 with DMSO, $\mathrm{NaCl}$ and water (reflux, 1 h) led to (+)-49 (92\%) which was then transformed into the unnatural enantiomer $(+)-\Delta^{9(12)}$-capnellene. ${ }^{33}$ 


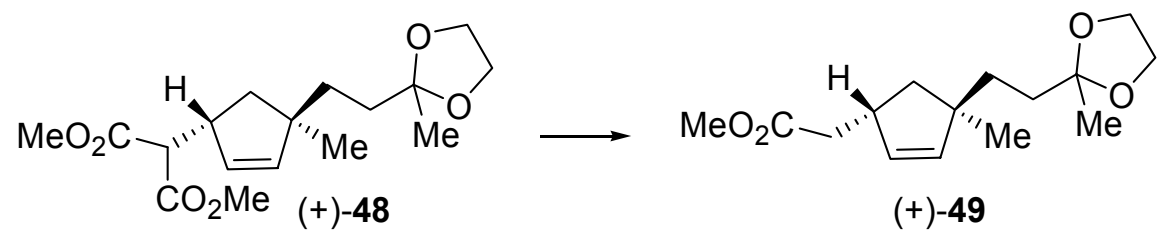

The demethoxycarbonylation of (-)-(1S,4S) $\mathbf{5 0}$ with DMSO, $\mathrm{LiCl}$ and water $\left(150^{\circ} \mathrm{C}, 4 \mathrm{~h}\right)$ led to $51(1 \mathrm{R}, 4 \mathrm{R})$. The enantiomer $(1 \mathrm{R}, 4 \mathrm{R})$ also led to the corresponding $(1 \mathrm{~S}, 4 \mathrm{~S})$ enantiomer. These esters were used in a synthesis of compounds to assess the bioactive conformations and chiral recognition of a moth sex pheromone. ${ }^{34}$<smiles>CCC[C@H]1C=C[C@H](C(C(C)=O)C(C)=O)[C@H]1[18OH]</smiles><smiles>[B][C@@H]1C[C@H](CCC)C=C[C@H]1CC(C)=O</smiles>

Treatment of racemic 52 with $\mathrm{DMSO}, \mathrm{LiCl}$ and water $\left(178^{\circ} \mathrm{C}, 4.3 \mathrm{~h}\right)$ led to racemic $\mathbf{5 3}$ $(69 \%) .^{35}$<smiles>CCOC(=O)C(C(=O)OCC)[C@H]1CC[C@@H](CO)C1</smiles>

52<smiles>CCOCC[C@H]1CC[C@H](CO)C1</smiles>

53

The decarbomethoxylation of (R)-diester 54 using $\mathrm{LiI} 3 \mathrm{H}_{2} \mathrm{O}$ in DMSO $\left(25 \mathrm{~min}, 180^{\circ} \mathrm{C}\right)$ led to (R)-55 (52\%). This intermediate was subsequently converted into $(1 \mathrm{R}, 4 \mathrm{~S}, 6 \mathrm{~S})-6$ hydroxybicyclo[2.2.2] octan-one. ${ }^{36}$

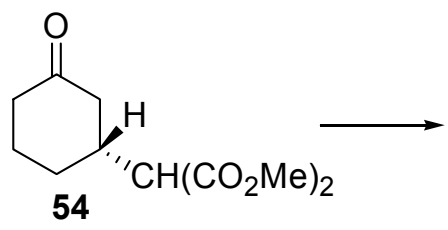<smiles>COC(=O)C[C@H]1CCCC(=O)C1</smiles>

55

Treatment of enantiomer 56 with $\mathrm{DMSO}, \mathrm{NaCl}$ and water $\left(150^{\circ} \mathrm{C}, 4 \mathrm{~h}\right)$ led to the decarbomethoxylated enantiomer 57 (92\%). This intemediate was converted into the chiral cadinane-sesquiterpene veticadinol. ${ }^{37}$ 


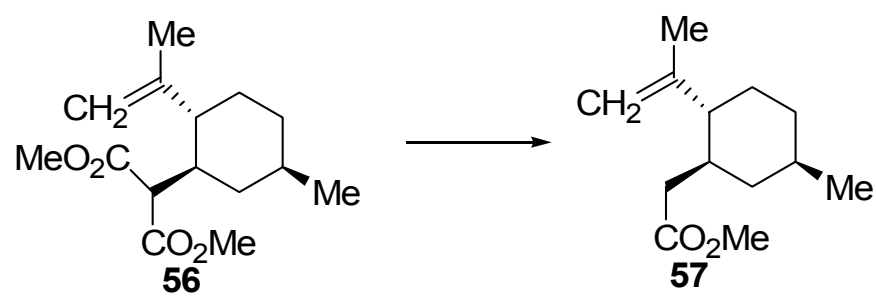

The demethoxycarbonylation of R-(+)-58 in DMSO, $\mathrm{NaCl}$ and water $\left(160^{\circ} \mathrm{C}, 24 \mathrm{~h}\right)$ led to $\mathrm{S}-(+)-59(74 \%){ }^{38 a}$ Racemic 58 on treatment with $\mathrm{DMSO}, \mathrm{LiCl}$ and water $\left(170^{\circ} \mathrm{C}, 24 \mathrm{~h}\right)$ gave racemic 59 (61\%). ${ }^{38 \mathrm{~b}}$ Similar conditions using DMSO, $\mathrm{LiCl}$, and water had been previously reported $\left(190^{\circ} \mathrm{C}, 6 \mathrm{~h}\right)$ for the conversion to the racemic mono ester $\mathbf{5 9}(84 \%){ }^{38 \mathrm{c}}$ Also racemic $\mathbf{5 8}$ with DMSO, $\mathrm{NaCl}$ and water $\left(170^{\circ} \mathrm{C}, 10 \mathrm{~h}\right)$ led to $\mathbf{5 9}(88 \%)$ which was converted into a substituted alanine analogue. ${ }^{38 \mathrm{~d}}$

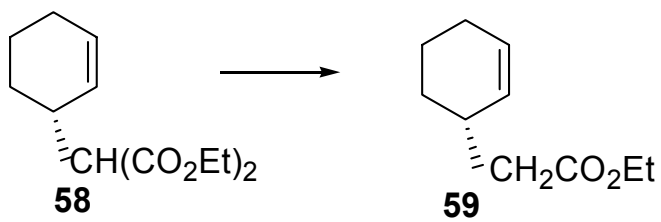

The demethoxycarbonylation of (S)-60 in DMSO, $\mathrm{NaCN}$ and water $\left(60^{\circ} \mathrm{C}, 48 \mathrm{~h}\right)$ afforded (R)-61 (80\%). ${ }^{39}$<smiles>COC(=O)C([18O])C1C=CC(C)=CC1</smiles>

Treatment of $\mathbf{6 2}$ with DMSO, $\mathrm{NaCN}$ and water $\left(110^{\circ} \mathrm{C}, 24 \mathrm{~h}\right)$ led to racemic $\mathbf{6 3}(62 \%){ }^{40}$<smiles>COCC(CC1C=CC=CC1)C(=O)OC</smiles>

The deethoxycarbonylation of diester $\mathbf{6 4}$ with DMSO, $\mathrm{NaCl}$ and water (reflux, $22 \mathrm{~h}$ ) led to racemic $\mathbf{6 5}(81 \%){ }^{41}$ 
<smiles>CCOC(=O)CCC1C(C)=CCCC1(C)C</smiles>

The demethoxycarbonylation of $\mathbf{6 6}$ in $\mathrm{DMSO}, \mathrm{LiCl}$ and water (reflux, $45 \mathrm{~min}$ ) led to $\mathbf{6 7}$ $(90 \%)$, an intermediate useful in studies to evaluate the application of silicon-containing compounds in synthesis. ${ }^{42}$

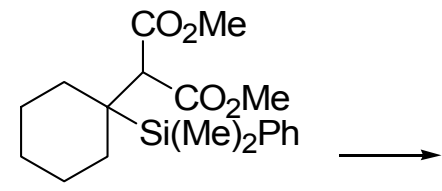

66

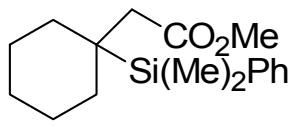

67

Treatment of $68 \mathbf{a}$ or $\mathbf{6 8 b}$ with $\mathrm{DMSO}, \mathrm{NaCN}$ and water $\left(70^{\circ} \mathrm{C}, 36 \mathrm{~h}\right)$ led to $69 \mathrm{a}(70 \%)$ or 69b $(60 \%)$, respectively. The lower temperature was necessary to avoid extensive rearrangements of the double bonds. ${ }^{43}$

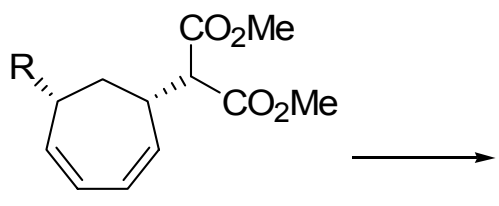

68<smiles>[R]C1C=CC=CC(CC(C)=O)C1</smiles>

69

$a, R=H ; b, R=M e$

A mixture of the enantiomer $\mathbf{7 0}$ in DMSO, $\mathrm{LiCl}$ and water $\left(160^{\circ} \mathrm{C}, 3 \mathrm{~h}\right)$ led to enantiomer $\mathbf{7 1}$ $(87 \%){ }^{44}$
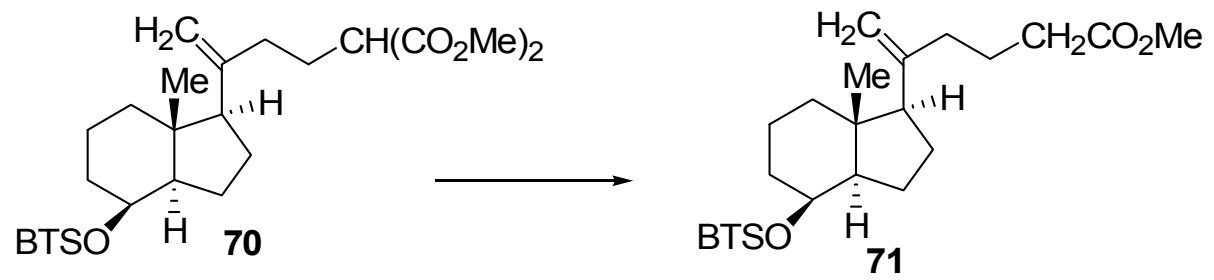

The demethoxycarbonylation of optically active 72 using $\mathrm{NaCN}$ in DMSO (no experimental details) led to $\mathbf{7 3}$ which was used in a total synthesis of optically active sesquiterpenes albolic acid and ceroplastol II, which have been found in the wax secretions of a scale insect. ${ }^{45}$ 


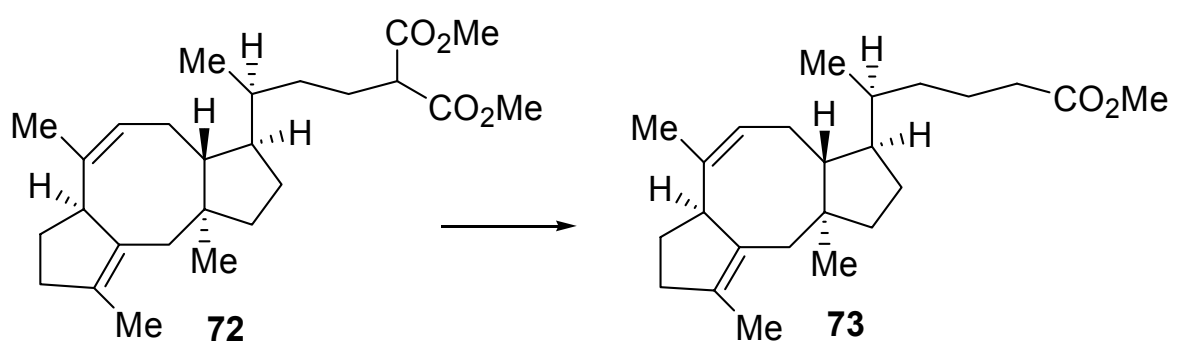

In a multi-gram scale up, treatment of 74 with $\mathrm{DMSO}, \mathrm{NaCl}$ and water $\left(170-180^{\circ} \mathrm{C}, 2.5 \mathrm{~h}\right)$ led to $75(80 \%){ }^{46}$
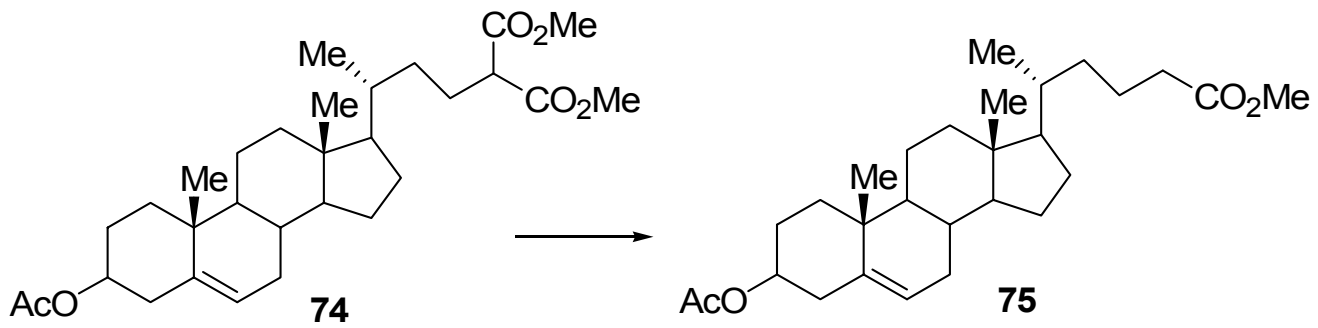

Treatment of enantiomer 76 with DMSO and $\mathrm{NaCN}$ ( heat , 6 h) led to enantiomer 77 $(57 \%){ }^{47}$

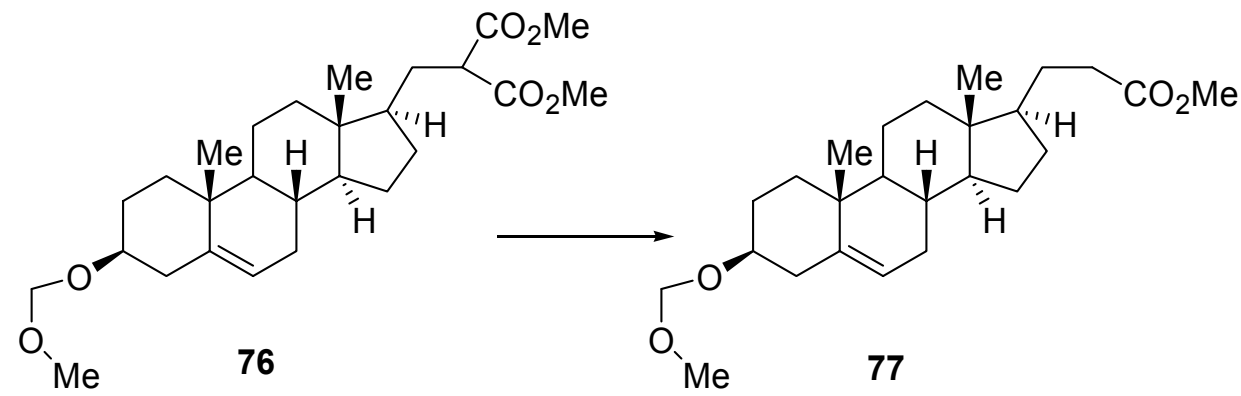

3.1.2.3. From aryl substituted malonate esters. The enantioselective conjugate addition of diethyl zinc with chiral phosphorus ligands to alkylidene malonates led to 3-ethyl substituted malonate esters. For example, the deethoxycarbonylation of 78 with DMSO, $\mathrm{LiCl}$ and water $\left(160^{\circ} \mathrm{C}, 15 \mathrm{~h}\right.$ ) led to $(\mathrm{R})-79$ (quantitative, $64 \%$ ee). ${ }^{48}$

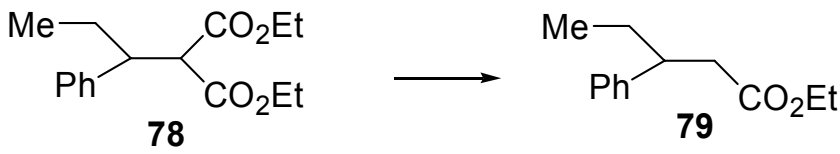

The decarbomethoxylation of (R)-80 with DMSO, $\mathrm{NaCl}$ and $\mathrm{H}_{2} \mathrm{O}\left(200^{\circ} \mathrm{C}, 20\right.$ min) in a microwave cavity led to $(\mathrm{S})-\mathbf{8 1}(80 \%){ }^{49}$ 
<smiles>C=CC(c1ccc(Cl)cc1)C(C(C)=O)C(C)=O</smiles>

$(\mathrm{R})-80$<smiles>C=CC(CC(C)=O)c1ccc(Cl)cc1</smiles>

$(\mathrm{S})-81$

The demethoxycarbonylation of $\mathbf{8 2}$ ( no conditions listed) led to 83. Other substituted analogues were also reported. ${ }^{50}$<smiles>COC(=O)CC(C(C)=O)C(CC(C)=O)c1ccccc1</smiles>

82<smiles>CC(=O)CC(CC(C)=O)c1ccccc1</smiles>

83

The demethoxycarbonylation of $\mathbf{8 4}$ (86\%ee) was accomplished by using DMSO, $\mathrm{NaCl}$ and an aqueous phosphate buffer $\left(170^{\circ} \mathrm{C}, 2.75 \mathrm{~h}\right)$ to afford $\mathbf{8 5}(38 \%$, with no significant loss of enantiomeric purity), which was used as an intermediate for the preparation of cardiotonic agents. ${ }^{51}$<smiles>CC(=O)C(C)C(C)C(=O)c1ccc(N)cc1</smiles>

84<smiles>CC(=O)CC(C)C(=O)c1ccc(N)cc1</smiles>

85

Treatment of 86 with DMSO, $\mathrm{NaCl}$ and water $\left(135-170^{\circ} \mathrm{C}, 3 \mathrm{~h}\right)$ led to $87(84 \%)$. This was converted into a hapten for the radioimmunoassay of bupropion (a non tricyclc antidepressant). ${ }^{52}$<smiles>CCOC(=O)C(Cc1ccc(C#N)cc1Cl)C(=O)OCC</smiles><smiles>CCOC(=O)CCc1ccc(C#N)cc1Cl</smiles>

87

The quaternary salt $\mathbf{8 8}$ and diethyl malonate (DMF, $\mathrm{K}_{2} \mathrm{CO}_{3}, 156^{\circ}, 39$ h) led to 90 (70-75\%). Shorter reaction times led to $\mathbf{8 9}$, which on demethoxycarbonylation in the presence of KI led to 90. This compound has been isolated from the roots of an endemic Guyana tree. ${ }^{53}$ 

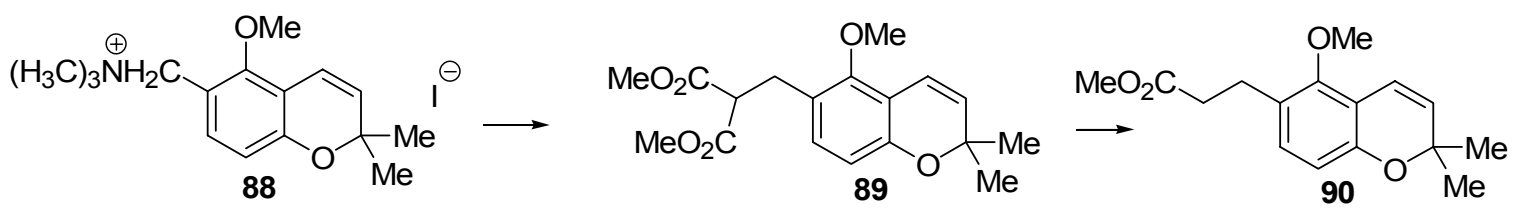

The demethoxycarbonylations of 91a-f on treatment with DMSO, $\mathrm{LiCl}$ and $\mathrm{H}_{2} \mathrm{O}\left(100^{\circ} \mathrm{C}, 3 \mathrm{~h}\right)$ led to the respective esters $92 \mathbf{a}-\mathbf{f}(56-86 \%) .{ }^{54}$

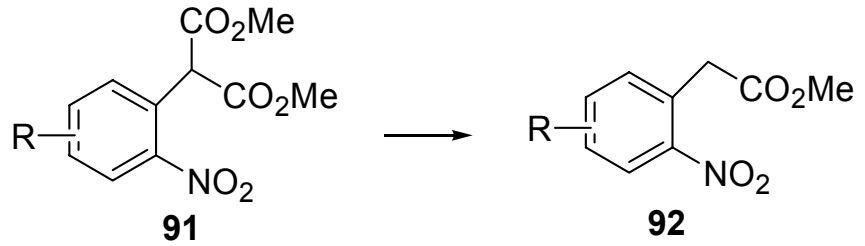
$\mathrm{a}, \mathrm{R}=5-\mathrm{Cl} ; \mathrm{b}, \mathrm{R}=4-\mathrm{Cl} ; \mathrm{c}, \mathrm{R}=\mathrm{OMe}$;
d, $R=4-B r ; e, R=4-F ; f, R=6-C l$

The deethoxycarbonylation of 93 with $\mathrm{DMSO}, \mathrm{NaCl}$ and water $\left(110^{\circ} \mathrm{C}, 3 \mathrm{~h}\right)$ led to the quinone $94(83 \%){ }^{55}$<smiles>CCOC(=O)C1=C(Cl)C(=O)c2ccccc2C1=O</smiles>

93<smiles>CCOCCC1=C(Cl)C(=O)c2ccccc2C1=O</smiles>

94

3.1.2.4. From 2-heterocyclic substituted malonic esters. The deethoxycarbonylation of 95 using DMSO, $\mathrm{NaCl}$ and water led $96(96 \%) .{ }^{56}$

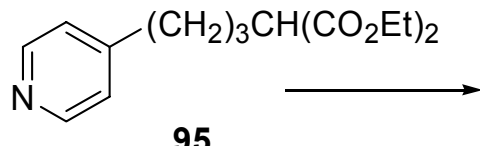

95<smiles>CCOC(=O)Cc1ccncc1</smiles>

96

Diester (-)-97 (98\%ee) on treatment with DMSO, $\mathrm{NaCl}$ and water $\left(120^{\circ} \mathrm{C}, 16 \mathrm{~h}\right)$ led to (-)-(R)$98(58 \%)^{57}$<smiles>COC(=O)C(C(=O)OC)[C@H]1C=CCN(C(C)=O)C1</smiles>

97<smiles>CC(=O)C[C@@H]1C=CCN(C(C)=O)C1</smiles>

98 
Upon treating the substituted indole 99 with $\mathrm{DMF}, \mathrm{LiCl}, \mathrm{Et}_{3} \mathrm{~N} \cdot \mathrm{HCl}\left(130^{\circ} \mathrm{C}, 4 \mathrm{~h}\right)$, the demethoxycarbonylated indole $\mathbf{1 0 0}$ was obtained (85\%). The N-BOC and benzyl ester functionalities were not affected. This intermediate was subsequentially converted to a tetracyclic ABCE Strychnos alkaloid precursor in an enantioselective manner. ${ }^{58}$<smiles>COC(=O)c1[nH]c2ccccc2c1C[C@H](COCc1ccccc1)N(Cc1ccccc1)C(=O)O</smiles>

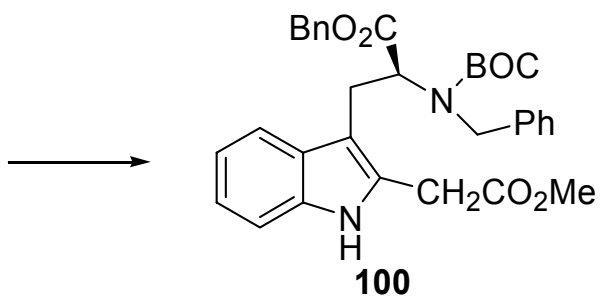

The synthesis of a 2-allyl substituted thiophene 102 (80\%) was accomplished by treatment of the diester 101 with DMSO, $\mathrm{NaCl}$ and water $\left(150-155^{\circ} \mathrm{C}, 8 \mathrm{~h}\right) .{ }^{59}$

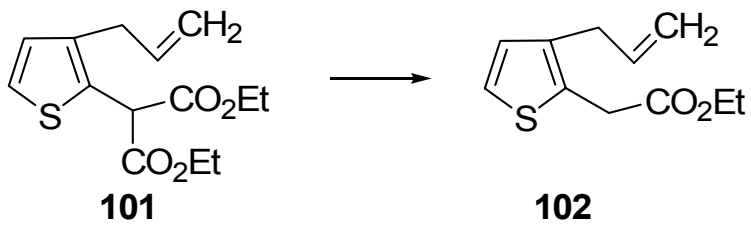

The decarbomethoxylation of racemic 103 with $\mathrm{DMSO}, \mathrm{NaCN}$ and water $\left(118^{\circ} \mathrm{C}, 3 \mathrm{~h}\right)$ led to monoester $104(79 \%)$. ${ }^{60}$

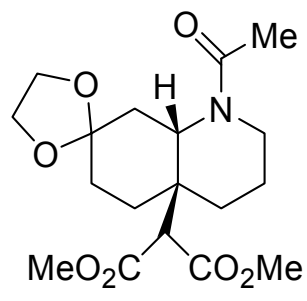

103<smiles>COC(=O)C[C@]12CCCN(C(C)=O)[C@@H]1CC1(CC2)OCCO1</smiles>

104 racemic

The decarboethoxylation of the pyrrolidine $105(2 \mathrm{~S}, 4 \mathrm{R})$ with $\mathrm{DMSO}, \mathrm{NaCl}$ and water $\left(160^{\circ} \mathrm{C}, 1 \mathrm{~h}\right)$ led to $\mathbf{1 0 6}(2 \mathrm{~S}, 4 \mathrm{R})$ [ $88 \%$ for 2 steps which involve a prior Michael addition] in which the protective silyl and BOC groups remained intact. This intermediate was converted into the desired lactam in two steps. ${ }^{61 \mathrm{a}, \mathrm{b}}$

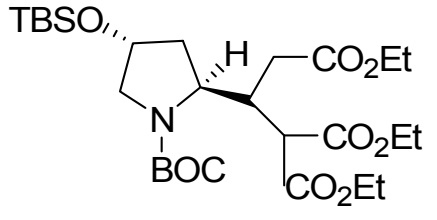

105 (2S, 4R)

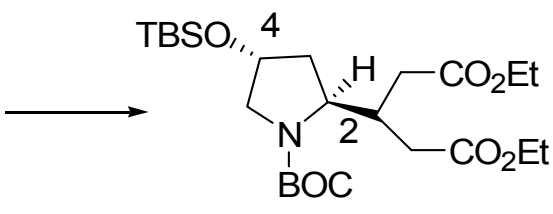

106 (2S, 4R) 
The dithioketal 107 on treatment with DMSO, $\mathrm{NaCl}$ and water $\left(155-160^{\circ} \mathrm{C}, 4 \mathrm{~h}\right)$ led to corresponding ester $\mathbf{1 0 8}$ with the dithio ketal functionality intact. This intermediate, in a series of subsequent steps, was converted into the $\delta$-dioxo analogues. ${ }^{62}$
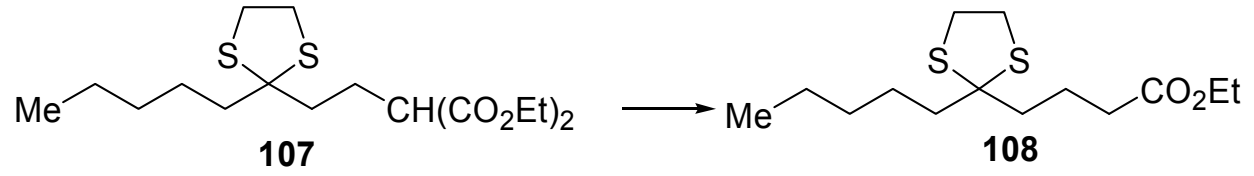

The demethoxycarbonylations of optically pure diesters $\mathbf{1 0 9} \mathbf{a}, \mathbf{b}, \mathbf{c}$ in $\mathrm{DMSO}, \mathrm{NaCl}$ and water $\left(150^{\circ} \mathrm{C}, 2-3 \mathrm{~h}\right)$ afforded the respective asymmetric succinic semialdehyde derivatives 110a,b,c $(63-81 \%){ }^{63}$

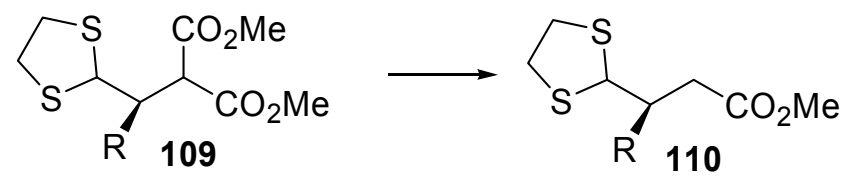

$$
a, \mathrm{R}=\left(\mathrm{CH}_{2}\right)_{2} \mathrm{Ph}: \mathrm{b}, \mathrm{R}=\mathrm{p}-\mathrm{NO}_{2} \mathrm{C}_{6} \mathrm{H}_{4} ; \mathrm{c}, \mathrm{R}=\text { biphenyl }
$$

Treatment of diastereoisomers 111 with DMSO, $\mathrm{LiCl}$ and water $\left(190^{\circ} \mathrm{C}, 5 \mathrm{~h}\right)$ led to $112 \mathrm{a}$ and $112 \mathrm{~b}(65 \%$, ratio $2.2: 1)$ which were separated by chromatography. Compound 112a, in a series of steps, was converted into dolabellane skeleton. ${ }^{64}$
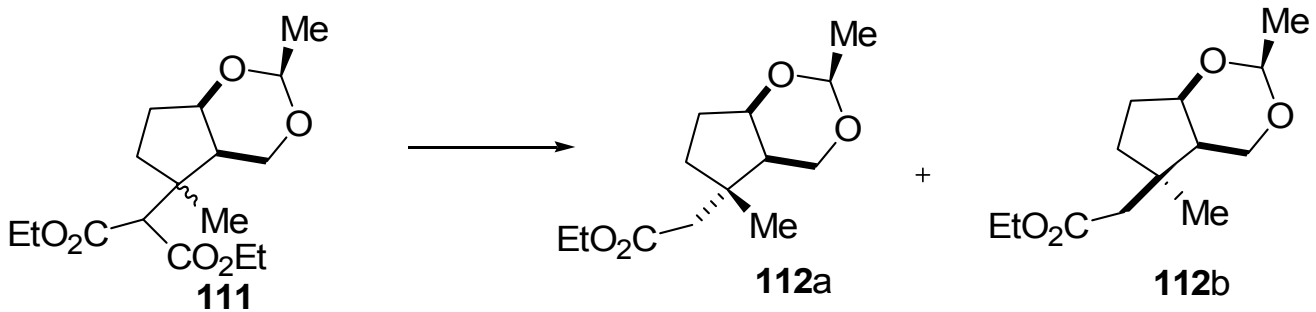

The demethoxycarbonylation of diester 113 with $\mathrm{DMSO}, \mathrm{NaCl}$ and water $\left(160^{\circ} \mathrm{C}, 24 \mathrm{~h}\right)$ led to enantiomer $114(75 \%)$. In a subsequent series of steps this intermediate was converted into the insect sex attractants (-)-anastrephin and (-)-epianastrephin. ${ }^{65}$
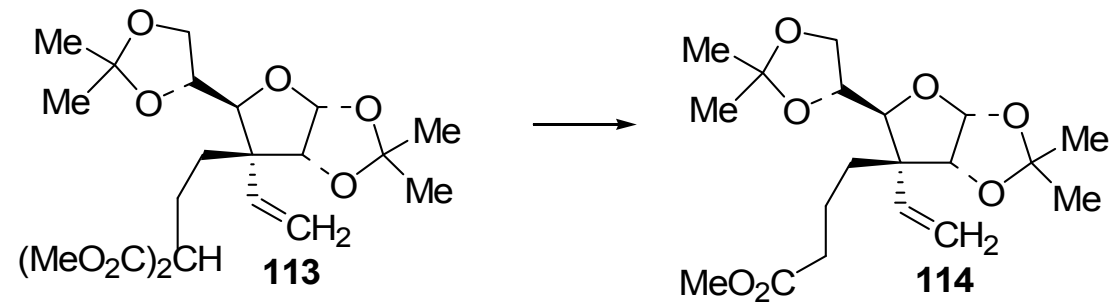
The Michael addition of the anion to $\mathbf{1 1 5}$ followed by demethoxycarbonylation using DMSO, $\mathrm{NaCl}$ and water (no conditions reported) led to enantiomeric 116 (55\% for the two steps). This intermediate was used in an enantiospecific synthesis of sesbanimide. ${ }^{66}$<smiles>COC(=CC=CC1OCO[C@H](C2COC(C)(C)O2)[C@@H]1OCc1ccccc1)C(C)C</smiles><smiles>COCCC1[C@H](c2ccccc2)OCO[C@H]1C1COC(C)(C)O1</smiles>

The deethoxycarbonylation of 117 using DMSO, LiCl and water (reflux, 2 h) afforded 118 (quantitatively). ${ }^{67}$<smiles>CCOC(=O)C1OC2(C)OC(C1OC)C(C(C(=O)OCC)C(C)C)O2</smiles>

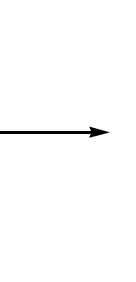<smiles>CCOCCC1OC2OC(C)(C)OC1C2OC</smiles>

The demethoxycarbonylation of 119 using DMSO, $\mathrm{NaCl}$ and water $\left(160^{\circ}, 1 \mathrm{~h}\right)$ led to optically active 120 (89\%) which was used in a synthesis of (+)-sebanimide and (-)-sebanamide, antitumor alkaloids from the seeds of a leguminous plant. ${ }^{68}$

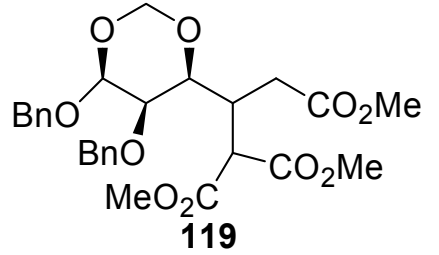<smiles>COCCC(CC(=O)OC)[C@H]1OCO[C@H](OBr)[C@H]1OBr</smiles>

The ketal (R)-121 on treatment with $\mathrm{DMSO}, \mathrm{NaCN}$ and water $\left(160^{\circ} \mathrm{C}, 6 \mathrm{~h}\right)$ led to $(\mathrm{R})-\mathbf{1 2 2}$ $(72 \%){ }^{69}$<smiles>CCOC(=O)C(C[C@@](C)(C(=O)OCC)C1(C)OCCO1)OCC</smiles>

(R)-121<smiles>[R17][C@](C)(CCCOC(=O)OCC)C1(C)OCCO1</smiles>

The decarbomethoxylation of $\mathbf{1 2 3}$ using DMSO, $\mathrm{NaCN}$ and water $\left(115^{\circ} \mathrm{C}, 2 \mathrm{~h}\right)$ led to racemic mono ester 124 (90\%), which was then converted into a dihydrofuran analogue of leukotriene $\mathrm{A}_{4}{ }^{70}$ 

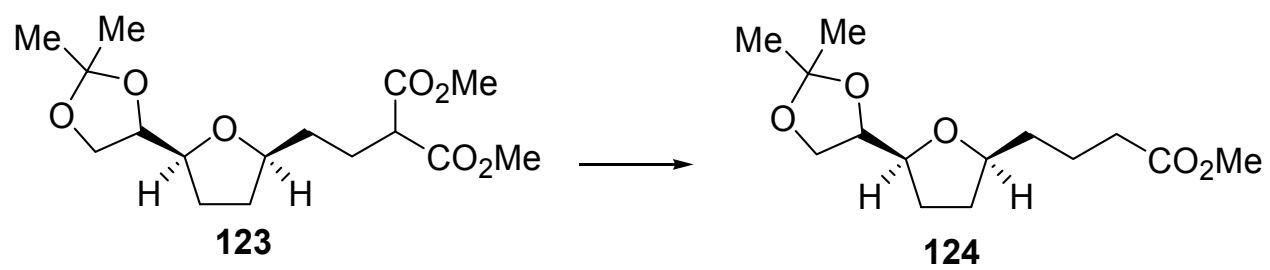

Treatment of 125 with DMSO, $\mathrm{NaCl}$ and water $\left(160^{\circ} \mathrm{C}, 4 \mathrm{~h}\right)$ led to racemic $126(91 \%) .{ }^{71}$

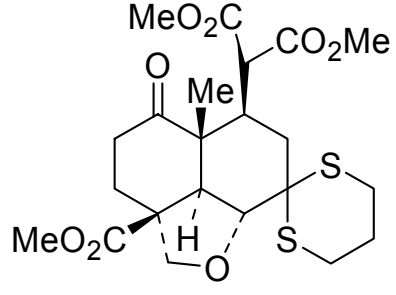

125

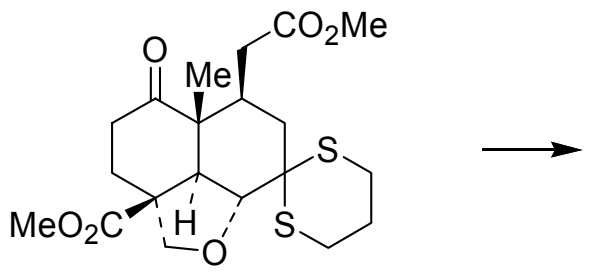

126

Some additional illustrative examples are tabulated in Table 1.

Table 1. Dealkoxycarbonylations of monosubstituted malonate esters

Starting material


<smiles>COCC(C(=O)OC)C(C)C(=O)OC</smiles><smiles>COC(=O)CC(C(=O)OC)[C@@H](Cc1ccccc1)C(OC)OC</smiles><smiles>C=C(C)CCCC(C(=O)OCC)C(=O)OCCCC(CC(C)=C(C)C)C(=O)OC</smiles>

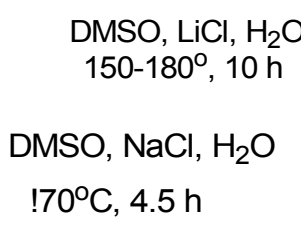<smiles>C=C(C)CCCCC(=O)OCC</smiles><smiles>O=[W]O[Mg]Cl</smiles>
$160^{\circ} \mathrm{C}, 2,5 \mathrm{~h}$

DMSO, $\mathrm{NaCl}, \mathrm{H}_{2} \mathrm{O}$ reflux, $4 \mathrm{~h}$<smiles>COCC(C)CC(C)CC(=O)OC</smiles><smiles>COC(=O)CC(C)CC(C)=O</smiles>

$60 \quad 80$

80<smiles>COC(=O)C(Cc1ccc(C(O)(C(F)(F)F)C(F)(F)F)o1)C(C)=O</smiles>

DMF, LiCl, $\mathrm{H}_{2} \mathrm{O}$ $160-165^{\circ} \mathrm{C}, 4 \mathrm{~h}$<smiles>CC(=O)CCc1ccc(C(O)(C(F)(F)F)C(F)(F)F)o1</smiles>
48 82<smiles>CCOC(=O)C(CC1CN(C)CCO1)C(=O)OCC</smiles>

DMF, $\mathrm{NaCl}, \mathrm{H}_{2} \mathrm{O}$ reflux, $23 \mathrm{~h}$<smiles>CCOC(=O)CCC1CN(C)CCO1</smiles>
98 83<smiles>C#C/C=C/CC(C(=O)OCC)C(=O)OCC</smiles><smiles>[R]S([R])(O)ONC#N</smiles>
$120^{\circ} \mathrm{C}, 3 \mathrm{~h}$<smiles>C#C/C=C/CCC(=O)OCC</smiles>
84<smiles>CCOC(=O)C(C[C@@H](CC)OCC)C(=O)OCC</smiles>

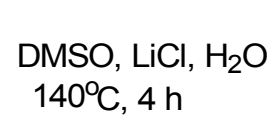<smiles>CCOC(=O)CC[C@@H](CC)OCC</smiles><smiles>CCOC(=O)C(CC=C1CC=C(C)CC1)C(=O)OCC</smiles><smiles>CCOC(=O)CCC=C1CC=C(C)CC1</smiles><smiles>CCOC(=O)C(CC([C@H]1COC(C)(C)O1)[C@H](Br)c1ccccc1)OCC</smiles>

DMSO
$180^{\circ} \mathrm{C}$<smiles>CCOC(=O)CC[C@@H](Cc1ccccc1)[C@H]1COC(C)(C)O1</smiles> 


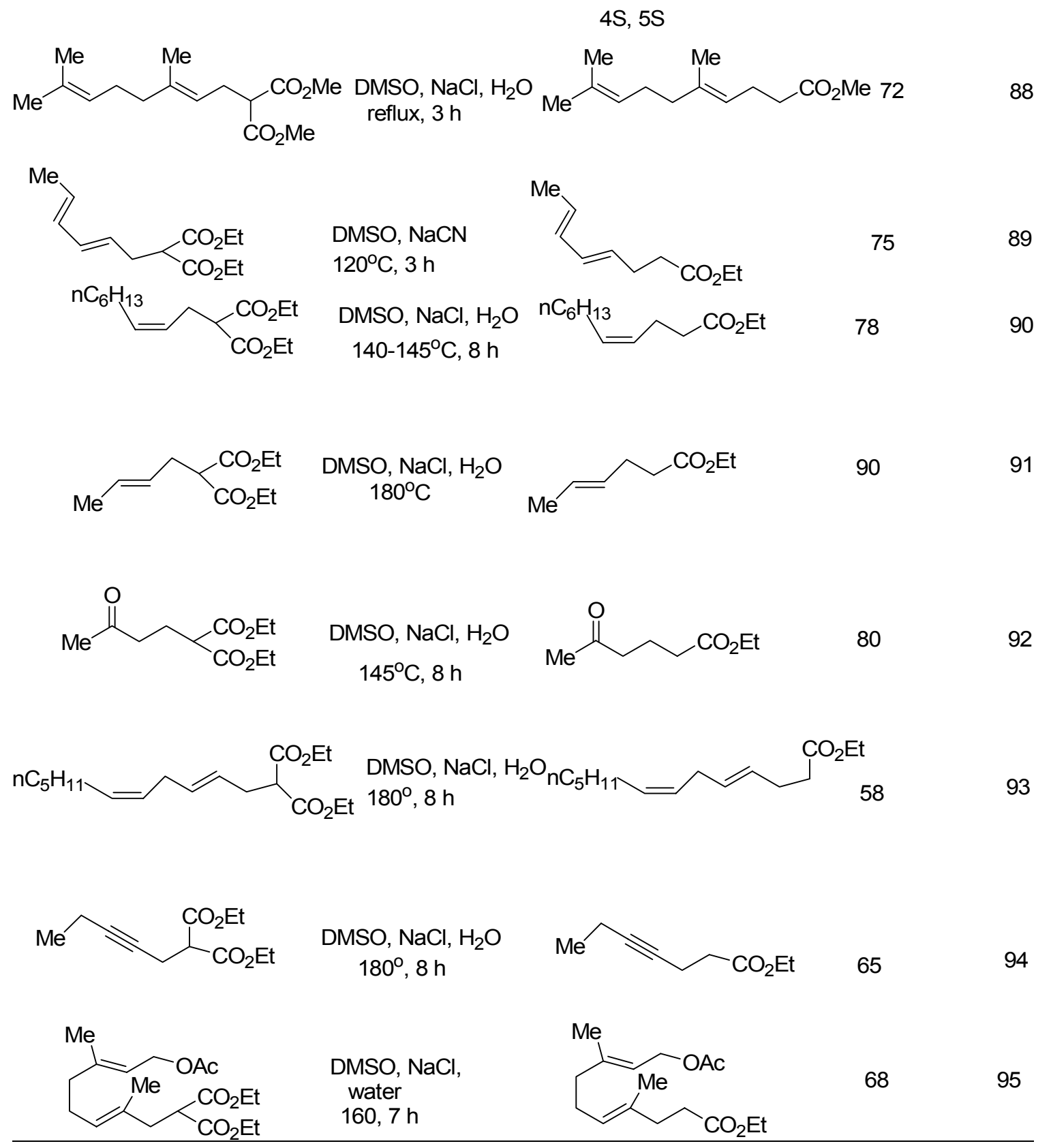

\section{Diesters}

\subsection{From substrates with two malonate ester functionalities}

The substituted 2,2-bipyridine 127 underwent bis-deethoxycarbonylation on heating in DMSO, $\mathrm{NaCl}$ and water (reflux, $2.5 \mathrm{~h}$, exclusion of light) to afford the bis-carboethoxyl ethyl substituted 2,2-bipyridine 128 (84\%). ${ }^{96}$ 


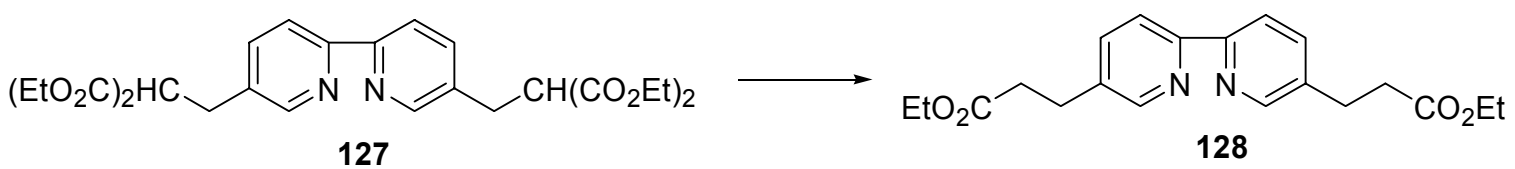

The bis-demethoxycarbonylation of the substituted N-methylphenothiazine 129 on treatment with DMI (1,3-dimethylimidazolidin-2-one), tetramethyl ammonium acetate and water $\left(140^{\circ} \mathrm{C}\right.$, $10 \mathrm{~h})$ led to $130(80 \%)$. These molecules were utilized in a synthesis of phenothiazinebipyridinium cyclophanes. ${ }^{97}$<smiles>COCCCCCCc1ccc2c(c1)N(C)c1ccc(CCCCOC)cc1S2</smiles>

In routes to pyrenophanes, the bis-demethoxylcarbonylation of $\mathbf{1 3 1}$ was accomplished on heating in $\mathrm{DMSO}, \mathrm{NaCl}$ and water $\left(160-170^{\circ} \mathrm{C}, 3 \mathrm{~h}\right)$ to yield $132(59 \%) .{ }^{98}$

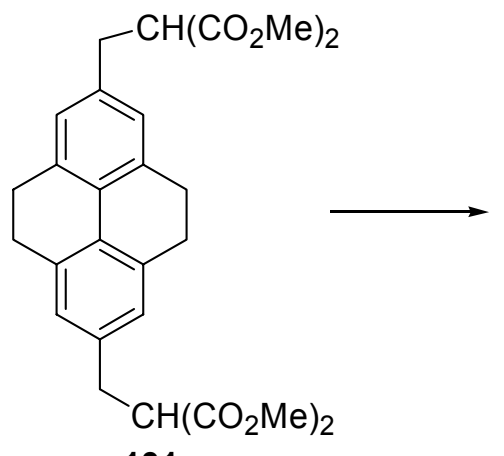

131

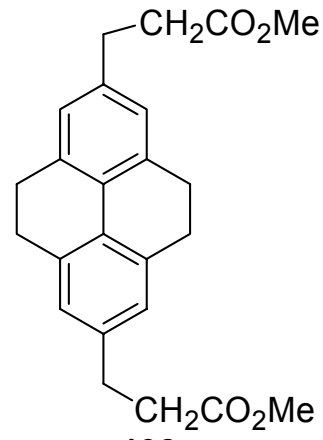

132

Treatment of tetra ester 133 with $\mathrm{DMSO}, \mathrm{LiCl}$ and water (no conditions given) led to diester $134(35 \%)$ which was used in a synthesis of [3.3.1]propellane-2,8-dione. ${ }^{99}$

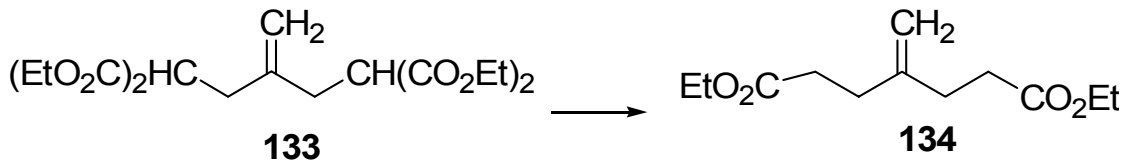

Treatment of a mixture of $\mathrm{KOH}$, dimethyl malonate (135) and chloromethallyl chloride (136) in DMF $\left(150^{\circ} \mathrm{C}, 0.5 \mathrm{~h}\right)$ led to dimethyl 4-methylenepimelate $(137,88 \%)$, the process involving a bis-demethoxycarbonylation. ${ }^{100}$ 


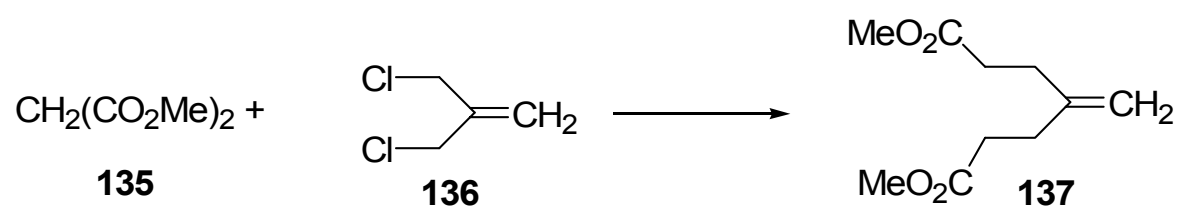

The conversion of the tetra ester 138 to the diester 139 (91\%) can be accomplished by treatment with DMSO, $\mathrm{LiCl}$ and water (reflux, $4 \mathrm{~h}) .{ }^{101}$
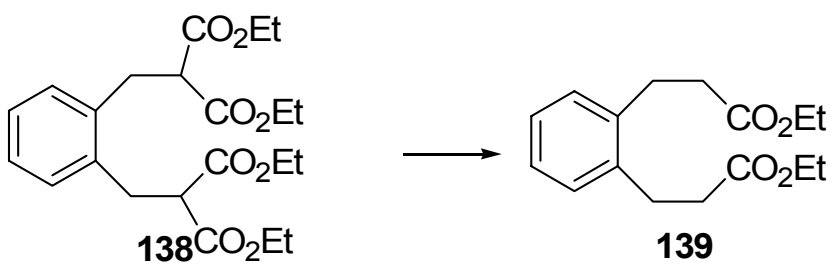

The bis-deethoxycarbonylation of $\mathbf{1 4 0}$ with DMSO, $\mathrm{NaCl}$, water ( reflux, $4 \mathrm{~h}$ ) led to the diester $141(79 \%){ }^{102}$<smiles>CCOCC(OCC)c1cc(OC)c(Cc2cc(OC)c(CC(=O)OCC)cc2OC)cc1OC</smiles>

\section{Demethoxycarbonylation - rearrangement}

Treatment of 142a $(\mathrm{n}=1)$ with $\mathrm{DMF}, \mathrm{NaCl}$ and water (reflux, $6 \mathrm{~h})$ led to the rearranged product 1,2,5,6-tetrahydroindolizine-3,7-dione $(\mathbf{1 4 3 a}, \mathrm{n}=1,33 \%)$. Under similar conditions $\mathbf{1 4 2} \mathbf{b}(\mathrm{n}=$ 2) led to 3,4,6,7,8,9-hexahydro-2H-quinolizine-2,6-dione (143b, $\mathrm{n}=2,44 \%){ }^{103 a}$ Additional examples and mechanistic considerations are reported in several later publications. ${ }^{103 b, c}$

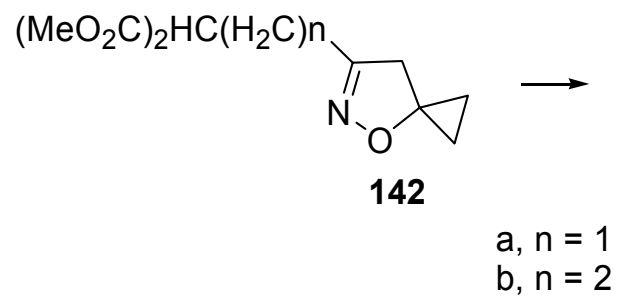<smiles>CCC(=O)C1CCC(=O)C=C1[Hg]</smiles>

$a, n=1$
$b, n=2$ 


\section{Aryl methyl susbstituted benzenes}

\subsection{From bis-dealkoxycarbonylations}

Treatment of 144 with DMSO, water and $\mathrm{NaCl}\left(160^{\circ} \mathrm{C}, 5 \mathrm{~h}\right)$ led to a double dealkoxycarbonylation to afford $\mathbf{1 4 5}$. $^{104}$

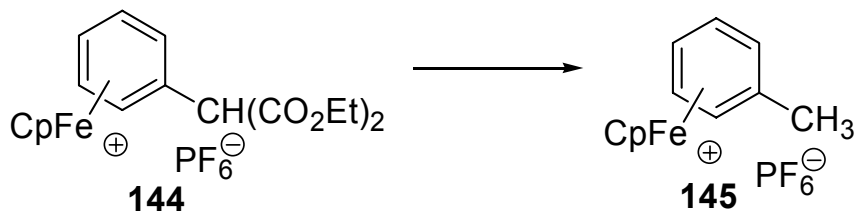

A number of aryl esters, readily available by $\mathrm{S}_{\mathrm{N}} \mathrm{Ar}$ substitution of 2-fluoro- or -2-chloro nitrobenzene by the anion of diethyl malonate, undergo bis-deethoxycarbonylations to afford 2methyl nitro benzenes. Treatment of 146 in DMSO, $\mathrm{NaCl}$, water $\left(160-170^{\circ} \mathrm{C}, 12 \mathrm{~h}\right)$ afforded $147(35 \%)$ with a higher yield of 147 (77\%) reported when using $\mathrm{MgCl}_{2} \cdot 6 \mathrm{H}_{2} \mathrm{O}$. ${ }^{105 \mathrm{a}}$

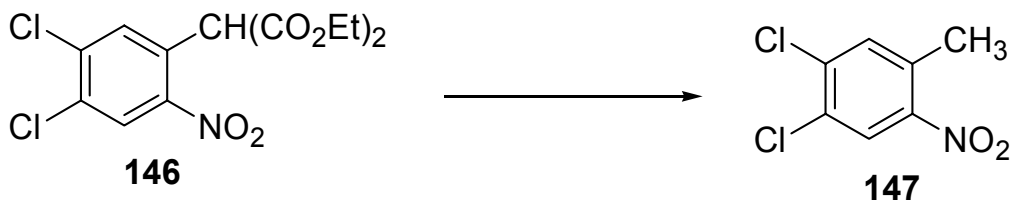

The analogue 148 undergoes a tetra-deethoxycarbonylation to afford $149(60 \%)$ on treatment with $\mathrm{MgCl}_{2} \cdot \mathrm{H}_{2} \mathrm{O}$ in DMA (reflux, $7 \mathrm{~h}$ ). ${ }^{105 a, b}$<smiles>CCOCC(Cc1cc(C=O)c(Cl)cc1[N+](=O)[O-])OCC</smiles><smiles>Cc1cc(C)c([N+](=O)[O-])cc1Cl</smiles>

\section{Esters}

\subsection{From disubstituted malonate esters}

The dealkoxycarbonylations are arranged on the basis of the two types of substituents attached to the malonate ester moiety.

\subsubsection{Bis-alkyl}

The deethoxycarbonylation of diester 150 with $\mathrm{DMSO}, \mathrm{LiCl}$ and water (reflux, $4 \mathrm{~h}$ ) led to 151 $(73 \%)$, a derivative for use in a study of hydrocarbon type dielectric fluids. ${ }^{106}$ 

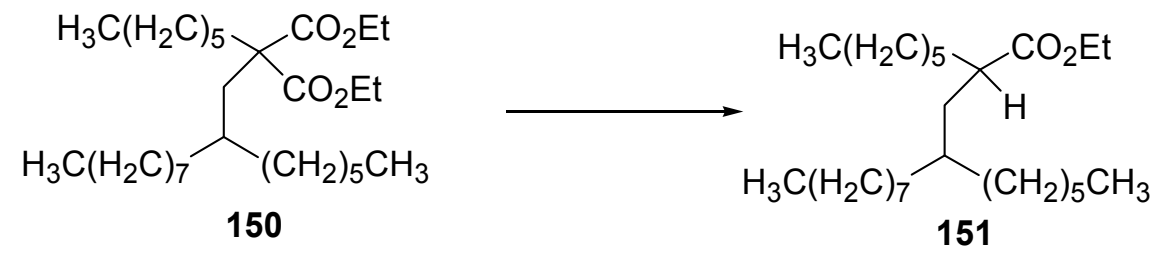

The synthesis of the deuterated ester 153 (90-95\%) was accomplished by heating 152 in DMSO, LiCl and water (reflux, $12 \mathrm{~h}$ ). ${ }^{107}$

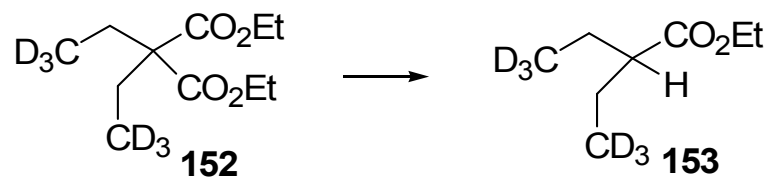

The quantitative deethoxycarbonylation of C,C-disubstituted malonates such as $\mathbf{1 5 4}$ supported on polystyrene can be accomplished by heating the polymer with $\mathrm{NaI}$ and anhydrous DMSO at $100^{\circ} \mathrm{C}$ to afford 155 . Calcium chloride in DMSO or $\mathrm{NaI}$ in nitromethane were also found to be useful for the deethoxycarbonylations. ${ }^{108}$

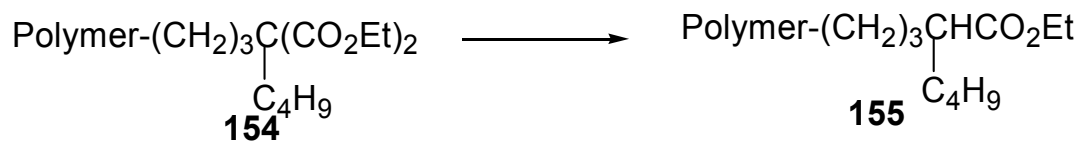

Compound 156, on solution in $\mathrm{DMSO}, \mathrm{LiCl}$ and water $\left(160^{\circ} \mathrm{C}, 4 \mathrm{~h}\right)$, led to the decarbomethoxylated product (S)-157 (66\%) with retention of the $\mathrm{Cbz}$ and Alloc amino protecting groups. ${ }^{109}$
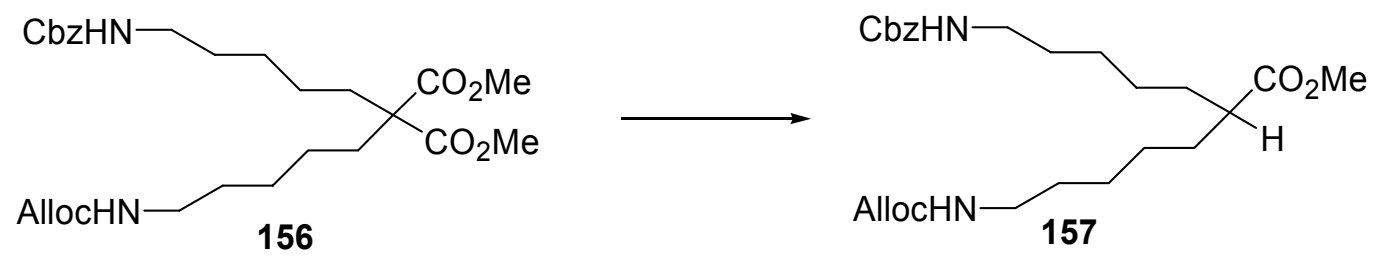

\subsubsection{Alkyl - benzylic}

The diester 158 on heating with DMSO, NaCN $\left(160-170^{\circ} \mathrm{C}, 4.5 \mathrm{~h}\right)$ afforded $159(85 \%) .{ }^{110}$
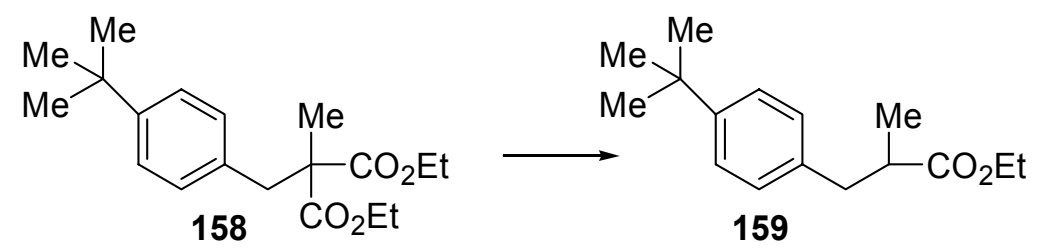

The $\beta$-silylated malonate ester $\mathbf{1 6 0}$ on treatment with DMSO, $\mathrm{LiCl}$ and water (reflux, $25 \mathrm{~min}$ ) led to $\mathbf{1 6 1}$ and $\mathbf{1 6 2}(68 \%)$ as a $70: 30$ mixture. ${ }^{11}$ 
<smiles>COC(=O)C(C)(C(C)=O)C([SiH2])[SiH2]c1ccccc1</smiles><smiles>CC(=O)C(C)C([GeH3])c1ccccc1</smiles>

$\begin{array}{ll}28 & 161\end{array}$
$\mathrm{Ph}(\mathrm{Me})_{2} \mathrm{Si}$,<smiles>CC(=O)C(C)Cc1ccccc1</smiles>

162

\subsubsection{Dimethylamino-benzyl}

Without the benefit of any reactions conditions, it was noted that treatment of $\mathbf{1 6 3}$ with DMSO and $\mathrm{NaCN}$ cleanly afforded $\mathbf{1 6 4} .^{112}$

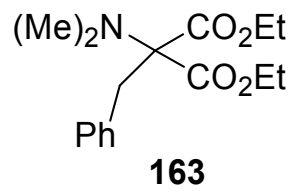

163

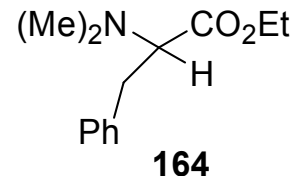

164

\subsubsection{Indanyl-carboethoxymethylene}

The triester 165 on heating in DMSO, $\mathrm{NaCl}$ and water $\left(178-183^{\circ} \mathrm{C}, 6 \mathrm{~h}\right)$ led to $166(85 \%) .{ }^{113}$<smiles>CCOC(=O)C(CC1CCc2ccccc21)(CC(C)(C)C)C(=O)OCC</smiles><smiles>C/C=C\C=C(/C)C(CC)C(CC)CC(=O)OCC</smiles>

\subsubsection{Benzocyclobutane substituted cyclopentane}

Treatment of diester 167 in $\mathrm{DMSO}, \mathrm{NaCN}$ and water $\left(90^{\circ} \mathrm{C}, 19 \mathrm{~h}\right)$ led to mono ester $168(78 \%)$ as an inseparable mixture of isomers. ${ }^{114 a}$ Several other related analogues were also dealkoxycarbonylated under similar conditions. ${ }^{114 b, c}$

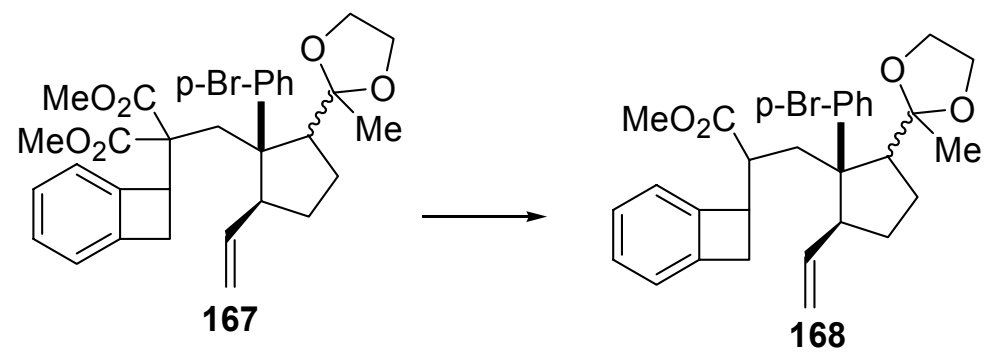

\subsubsection{Alkyl-heterocyclic}

The deethoxycarbonylation of 169 with DMSO, $\mathrm{LiCl}$ and water (reflux, $3 \mathrm{~h}$ ) yielded $\mathbf{1 7 0}(83 \%)$ which was used in a synthesis of an indoloquinolizidine. ${ }^{115}$ 


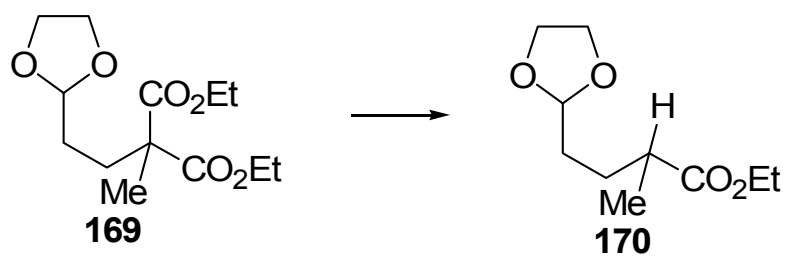

During the decarbomethoxylation of the benzothiazolone 171 in DMSO, KCN and water (reflux, $12 \mathrm{~h}$ ), the expected product $172(75 \%)$ along with the ring-opened 2-alkylsulfanyl aniline 173 (25\%) were isolated. ${ }^{116}$<smiles>CCOC(=O)C(CC)(CCn1c(=O)sc2ccccc21)OCC</smiles>

171<smiles>CCOC(=O)C(CC)CCn1c(=O)sc2ccccc21</smiles>

172<smiles>CCOC(=O)C(CC)CCNc1ccccc1SCC</smiles>

Methyl nonactate (+)-175 and 2-epi-methyl nonactate (-)-176 (overall yield 78\% in a 1:1 ratio and separated by chromatography) were prepared by heating diester 174 in DMSO with $\mathrm{NaCl}$ and water (reflux, $3 \mathrm{~h}) .{ }^{117}$
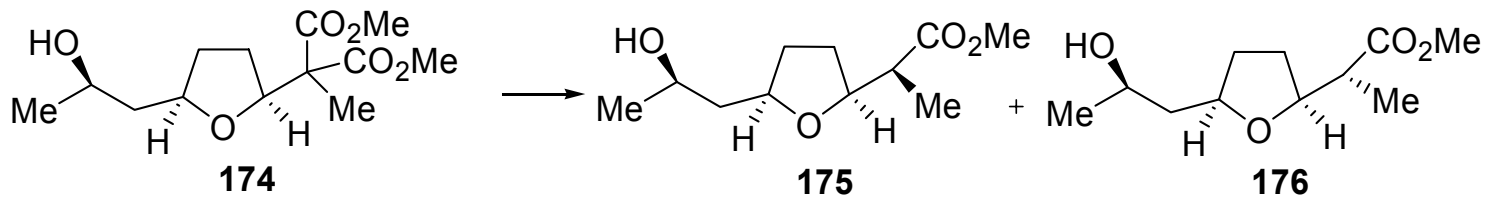

The deethoxycarbonylation of 177 was accomplished using $\mathrm{DMSO}, \mathrm{LiCl}$ and water $\left(180^{\circ} \mathrm{C}, 4\right.$ h) to afford $178(81 \%){ }^{118}$<smiles>CCOCC(C)(CCC(c1ccc(C)o1)[In]([In])[I+])CC(=O)OCC</smiles>

\subsubsection{Cycloalkyl-1,1-dicarboxylic esters}

The demethoxycarbonylation of the cyclopropane-1,1-dicarboxylic acid methyl ester (179) has been studied under several different conditions. With DMSO, $\mathrm{NaCl}$ and water $\left(160^{\circ} \mathrm{C}, 6 \mathrm{~h}\right)$ the three products 180, 181 and $\mathbf{1 8 2}$ were obtained in $73 \%$ yield with the trans/cis/ ring opening ratio of $27 / 21 / 52$. With $\mathrm{NaCN}$ in aqueous $\mathrm{DMF}\left(120^{\circ} \mathrm{C}, 48 \mathrm{~h}\right)$ total yield was $88 \%$ with the ratios of $50 / 34 / 16$. In the use of tetramethyl ammonium acetate in HMPA $\left(95^{\circ} \mathrm{C}, 4 \mathrm{~h}, 90 \%\right.$ yield) with the ratio being 70/30/0 with no ring opened product. ${ }^{119}$ 


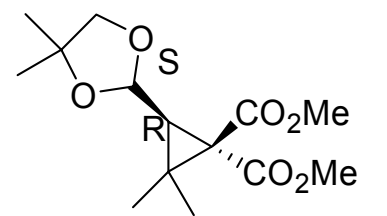

179

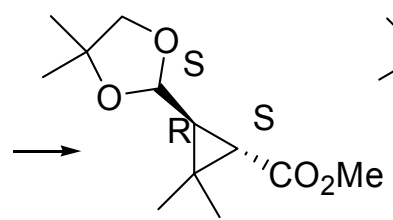

180

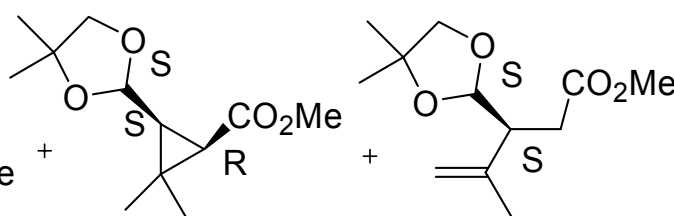

181

182

The dealkoxylcarbonylations of several sulfur- and alkoxy substituted cyclopropane derivatives have been evaluated. The demethoxycarbonylation of alkylthio or aryl thio analogues led to esters as an isomeric mixture with the trans isomers in a large excess, where as in the sulfonyl analogues the dealkoxycarbonylations were diasteroselective and led exclusively to the trans-derivatives. For example, the sulfonyl analogue $\mathbf{1 8 3}$ on treatment with DMSO, $\mathrm{NaCl}$ and water (reflux, $4 \mathrm{~h}$ ) led to trans-184. ${ }^{120 a, b, c}$<smiles>COC(=O)C1(C)C([Sb](=O)(=O)c2ccccc2)C1(C)C</smiles>

183

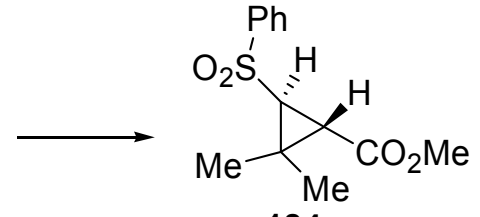

184

Treatment of $\mathbf{1 8 5}$ with $\mathrm{DMSO}, \mathrm{NaCl}$ and water (reflux) led to $\mathbf{1 8 6}(80 \%$, isomeric mixture). ${ }^{121}$
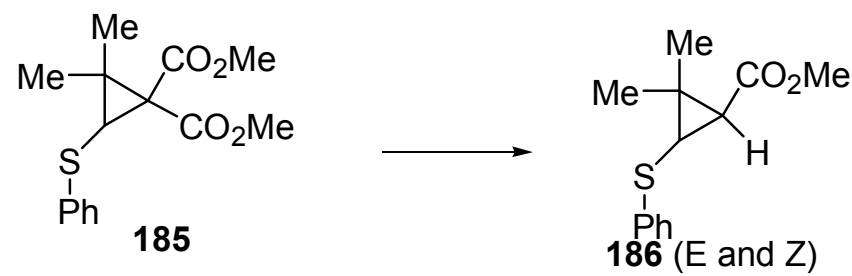

In a synthesis leading to 1,2,3-trisubstituted cyclopropanes, the demethoxycarbonylations of several isomeric cyclopropanes have been evaluated. Treatment of 187 with DMSO, $\mathrm{LiCl}$ and water $\left(195^{\circ} \mathrm{C}, 2 \mathrm{~h}\right)$ led to $\mathbf{1 8 8}(2 \mathrm{R}, 3 \mathrm{~S}, \mathrm{E})$ and $\mathbf{1 8 9}(96 \%)$ in a $1: 1$ product ratio which could be separated by chromatography. ${ }^{122}$

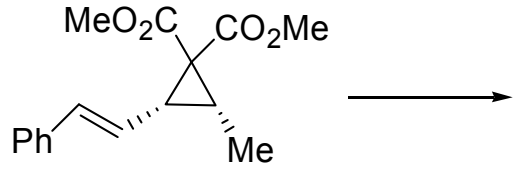

187

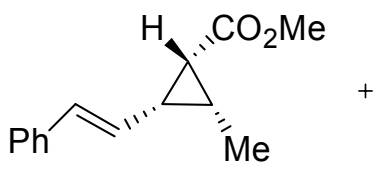

188

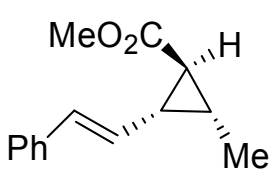

189

The diester 190 on treatment with DMSO and $\mathrm{NaCN}\left(150^{\circ} \mathrm{C}, 23 \mathrm{~h}\right)$ led to racemic $191(15 \%$, 9:1 trans:cis) which could be crystallized to obtain pure trans product. This was resolved to give 
enantiomerically pure 191 (1R,3R). This was converted into a cyclopropyl guanidine for evalution of of its activity against the sodium hydrogen exchanger isoform-I. ${ }^{123}$

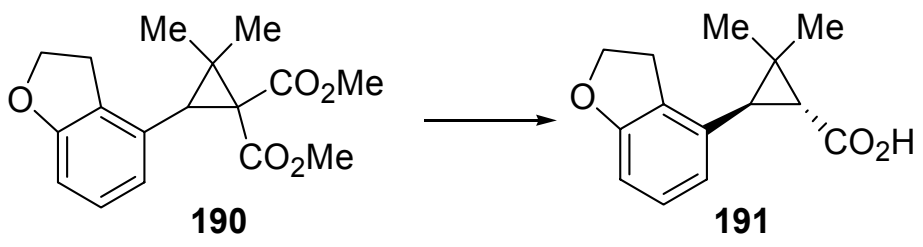

Treatment of 192 with DMSO and $\mathrm{NaCN}\left(160^{\circ} \mathrm{C}, 1.5 \mathrm{~h}\right)$ led to the demethoxycarbonylated products 193 and 194 (47\%, 1:1 ratio). ${ }^{124}$<smiles>COC(OC)C1(C)C(C=CC(F)(F)F)C1(C)C</smiles><smiles>COC(=O)C1[C@H](C)[C@@H](/C=C/C(F)(F)F)C1(C)C</smiles><smiles>CO[C@H]1[C@@H](/C=C/C(F)(F)F)C1(C)C</smiles>

Treatment of 195 in DMF, $\mathrm{NaCl}$ and water led to methyl caronate 196 (high yield) which could be converted into chrysanthemates. ${ }^{125}$<smiles>COCC1(OC)C(C(OC)OC)C1(C)C</smiles><smiles></smiles>

Treatment of 197a or 197b with DMSO, $\mathrm{LiCl}$ and water $\left(190^{\circ} \mathrm{C}\right.$, overnight $)$ afforded mono ester $198 \mathbf{a}(80 \%)$ or $\mathbf{1 9 8 b}(78 \%)$, respectively. ${ }^{126}$
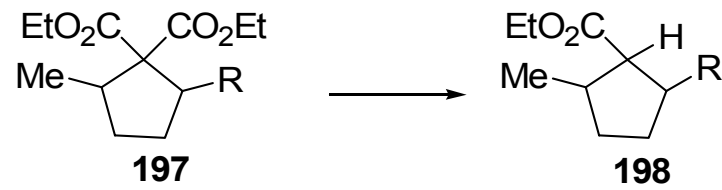

$\mathrm{a}, \mathrm{R}=\mathrm{H} ; \mathrm{b}, \mathrm{R}=\mathrm{Me}$

In a route to the total synthesis of kempane diterpenes, the intermediate racemic diesters 199a and 199b underwent demethoxycarbonylation on treatment with DMF, NaCN, and water $\left(120^{\circ} \mathrm{C}, 5 \mathrm{~h}\right)$ to afford the mono esters $\mathbf{2 0 0 a}(85 \%)$ and $\mathbf{2 0 0 b}(81 \%)$, respectively. ${ }^{127}$ 


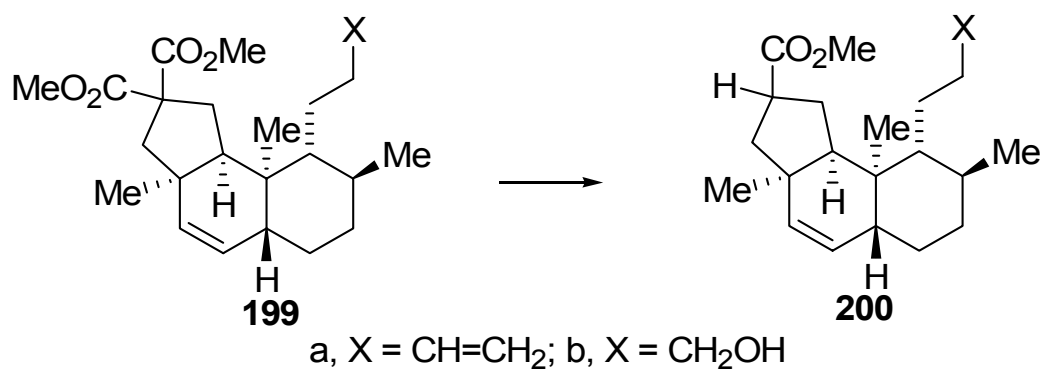

The demethoxycarbonylation of racemate 201 using DMSO, $\mathrm{LiCl}$ and water $\left(130^{\circ} \mathrm{C}\right)$ led to the product 202, with rearrangement of the double bond $(90 \%){ }^{128}$

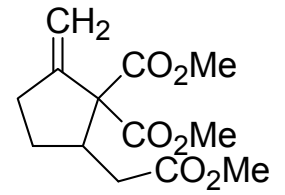

201

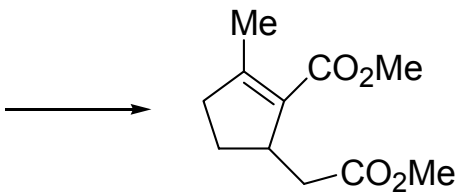

202

Treatment of 203 with DMSO and $\mathrm{NaCN}\left(160^{\circ} \mathrm{C}\right)$ led to $204(63 \%)$ which was converted into azanoradamantyl amine in a subsequent series of steps. ${ }^{129}$

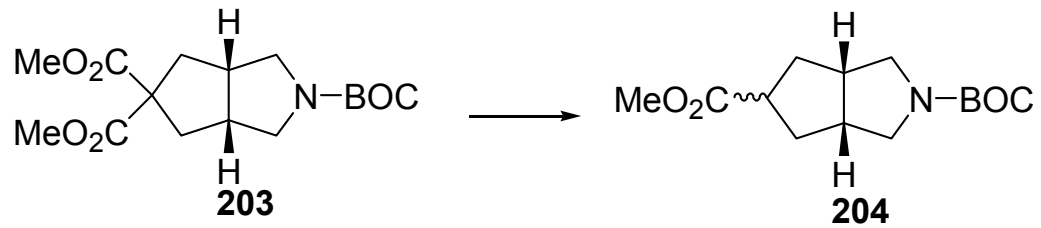

\subsubsection{Alkyl-alkenyl}

The diester 205 on treatment with DMSO, $\mathrm{NaCN}$ and water $\left(170^{\circ} \mathrm{C}, 5 \mathrm{~h}\right)$ led to $206(82 \%)$, an intermediate used in the synthesis of furanoid terpenes. ${ }^{130}$

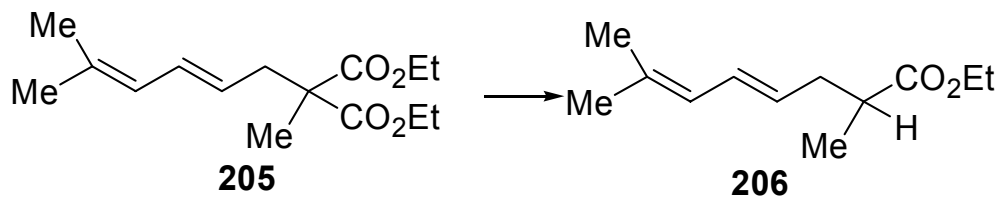

Treatment of 207 with DMSO, $\mathrm{NaCl}$ and water $\left(190^{\circ} \mathrm{C}, 12 \mathrm{~h}\right)$ led to $208(85 \%)$. This intemediate was converted into methyl 2,6,10-trimethyltridecanoate, a male-produced pheromone of several stink bugs. ${ }^{131}$<smiles>CCC/C(C)=C/CC/C(C)=C/CCC(C)(C)OC</smiles>
207<smiles>CCC/C(C)=C/CC/C(C)=C/CCC(C)C(C)OC</smiles> 


\subsubsection{Alkenyl-bromoalkyl}

Treatment of diester 209 with $\mathrm{NaCN}$ in DMSO and water led to decarboethoxylation and displacement of the terminal $\mathrm{Br}$ to afford cyano ester $210(60 \%){ }^{132}$

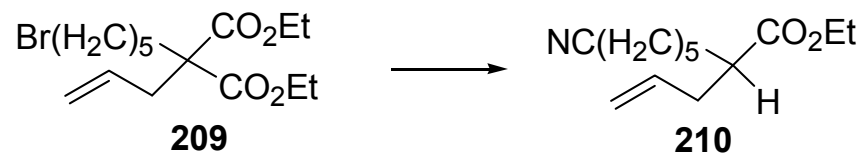

\subsubsection{Alkenyl-fluoro}

The deethoxycarbonylation of the $\alpha$-fluoro diester 211 to the $\alpha$-fluoro ester 212 (78\%) can be accomplished by heating in DMSO, $\mathrm{NaCl}$, and water (reflux, $4 \mathrm{~h}$ ). ${ }^{133}$

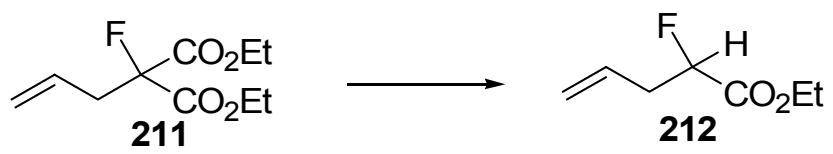

\subsubsection{Alkenyl-alkenyl}

Upon heating diester 213 in anhydrous DMSO and $\mathrm{KCN}\left(140^{\circ} \mathrm{C}, 43 \mathrm{~h}\right)$, the pseudo- $\mathrm{C}_{2}$ symmetrical carboxylic acid 214 (3R,1R) (93\%) was obtained. These analogues could be desymmetrized and utilized in a target-directed synthesis. ${ }^{134}$

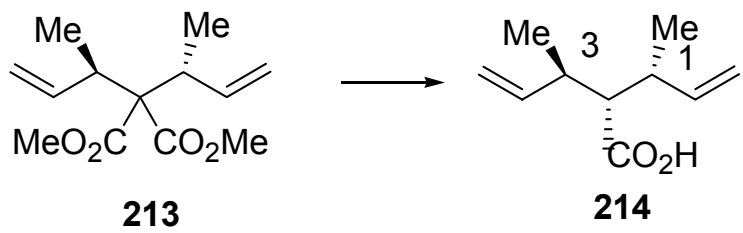

The decarbalkoxylations of several disubstituted malonates were shown to proceed in good yields when heated with $\mathrm{LiCl}$ and water in [bmim]Br to afford the corresponding esters. This ionic liquid functions as an alternative to the use of dipolar aprotic solvents such as DMSO or DMF. Upon heating diester 215 with $\mathrm{LiCl}$ and water in the presence of [bmim] br (217) $\left(160^{\circ} \mathrm{C}\right.$, $14 \mathrm{~h})$ the mono ester 216 (99\%) was obtained. ${ }^{135}$

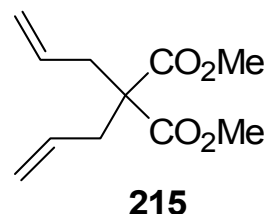

215

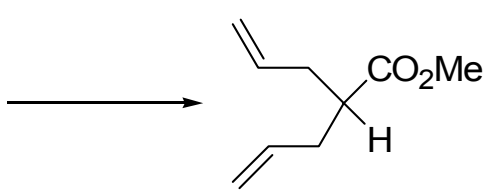

216

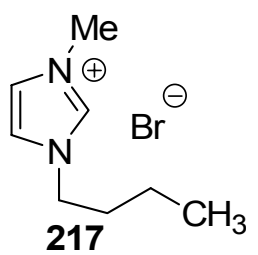

217

Treatment of 218 with $\mathrm{DMSO}, \mathrm{NaCN}$ and water $\left(95^{\circ} \mathrm{C}, 48 \mathrm{~h}\right)$ afforded $219(72 \%) .{ }^{136}$ 


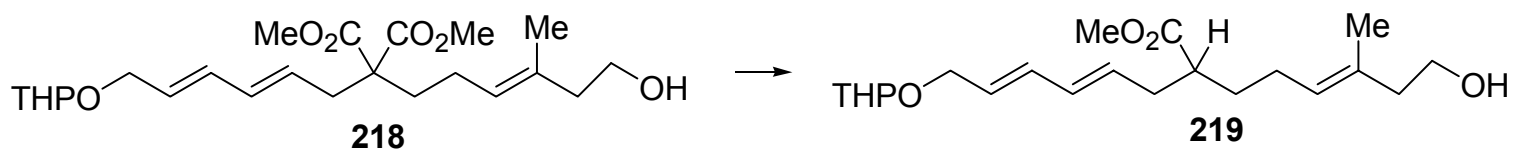

Treatment of 220 with $\mathrm{DMSO}, \mathrm{NaCN}$ and water $\left(95^{\circ} \mathrm{C}, 25 \mathrm{~h}\right)$, with the addition of more $\mathrm{NaCN}$, with stirring for $25 \mathrm{~h}$ at $95^{\circ} \mathrm{C}$ led to the decarbomethoxylated product $221(88 \%){ }^{137}$

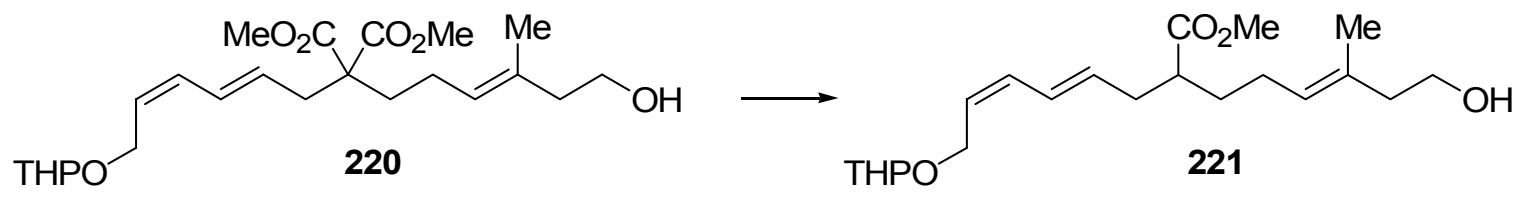

The demethoxycarbonylations of several disubstituted malonate esters with unsaturated side chains have been reported. A typical example is the conversion of $\mathbf{2 2 2}$ on treatment with DMSO, NaCN and water $\left(95^{\circ} \mathrm{C}, 3 \mathrm{~h}\right)$ to yield $223(81 \%) .{ }^{138}$

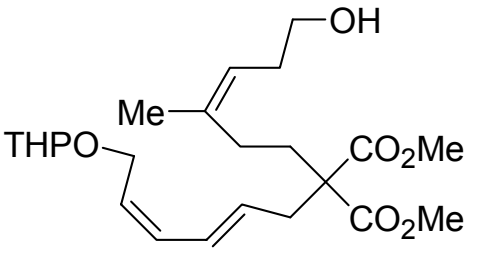

222

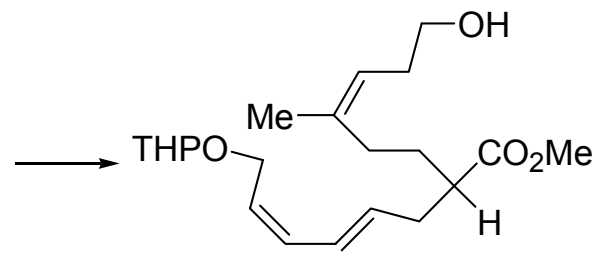

223

\subsubsection{Alkynyl - alkynyl}

Treatment of the bis-propargyl substituted diester $\mathbf{2 2 4}$ with DMSO, LiCl and water (reflux, 2 h) led to the deethoxycarbonylated product $225(82 \%){ }^{139}$

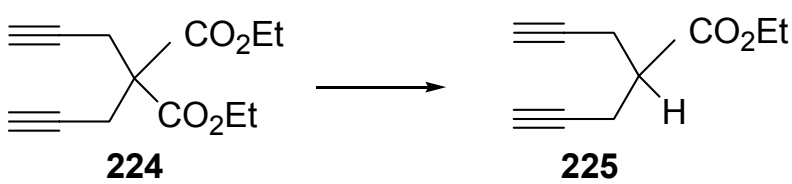

The demethoxycarbonylation of 226 with $\mathrm{DMSO}, \mathrm{NaCN}\left(100^{\circ} \mathrm{C}\right)$ led to $227(58 \%){ }^{140}$

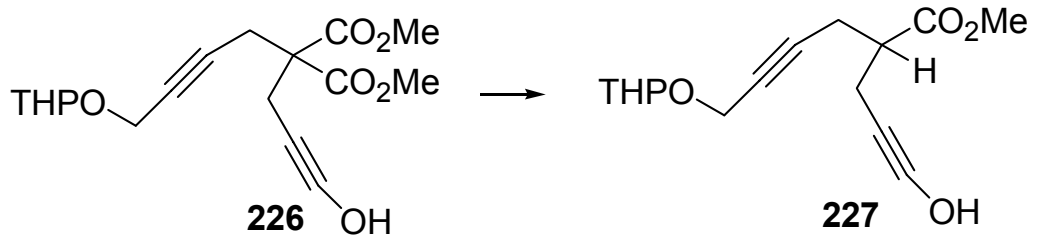

\subsubsection{Alkenyl-alkynyl}

Treatment of malonate ester 228 in DMSO and $\mathrm{NaCN}\left(120^{\circ} \mathrm{C}, 4 \mathrm{~h}\right)$ led to the demethoxylcarbonylated product $229(62 \%) .{ }^{141}$ 


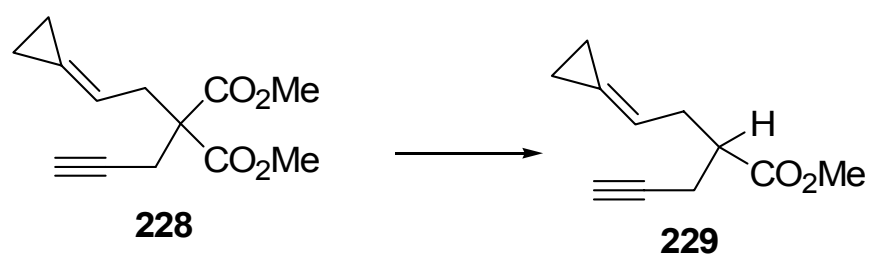

\subsubsection{Alkenyl-heterocyclic}

The substituted imidazole 230 on treatment with DMSO, $\mathrm{NaCN}$ and water $\left(120^{\circ} \mathrm{C}, 48 \mathrm{~h}\right)$ led to the deethoxycarbonylation product $\mathbf{2 3 1}(45 \%)$. Further elaboration of this product led to histamine analogues as potential cardiovascular selective $\mathrm{H}_{2}$ agonists. ${ }^{142}$
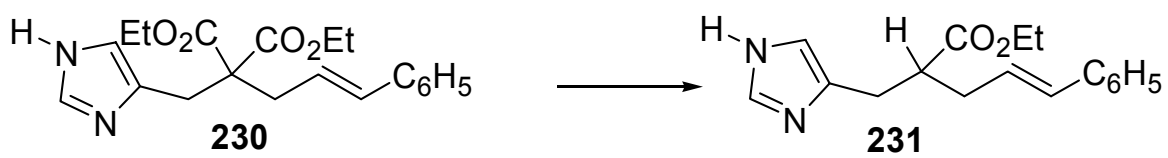

\subsubsection{Ethynyl-heterocyclic}

The malonate ester 232 (140 g) underwent a deethoxycarbonylation when heated in DMA or DMPU) with a large excess of $\operatorname{LiBr}\left(85^{\circ} \mathrm{C}, 16 \mathrm{~h}\right)$ to afford the (pyridonyl-1)propargyl acetic ester 233 (87\%, 99.5\% HPLC purity). This was a key intermediate for the synthesis of a selective inhibitor of a human rhinovirus. ${ }^{143}$<smiles>C#CC(C(=O)OCC)n1cccc(NC(=O)c2cc(C)on2)c1=O</smiles><smiles>C#CCC(OCC)n1cccc(NC(=O)c2cc(CC)on2)c1=O</smiles>

\subsubsection{Cyclopropyl-dichloroalkenyl}

A number of halo substituted 4-alkenoic esters have been prepared via the dealkoxycarbonylation procedure. For example, treatment of malonate ester $\mathbf{2 3 4}$ with DMSO, $\mathrm{NaBr}$ and water $\left(190^{\circ} \mathrm{C}, 8 \mathrm{~h}\right)$ led to monoester $235(80 \%){ }^{144}$
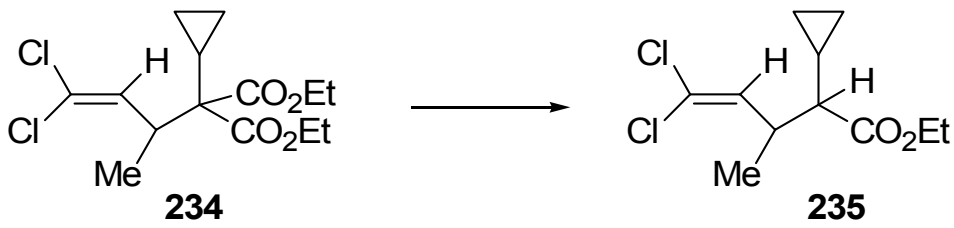

\subsubsection{Carbocyclic-1,1-dicarboxylic acid diesters}

Treatment of $\mathbf{2 3 6}$ with DMF, $\mathrm{LiCl}$ and water (reflux, $48 \mathrm{~h}$ ) led to $\mathbf{2 3 7}$ (41\%) and $\mathbf{2 3 8}(29 \%)$. ${ }^{145}$ 


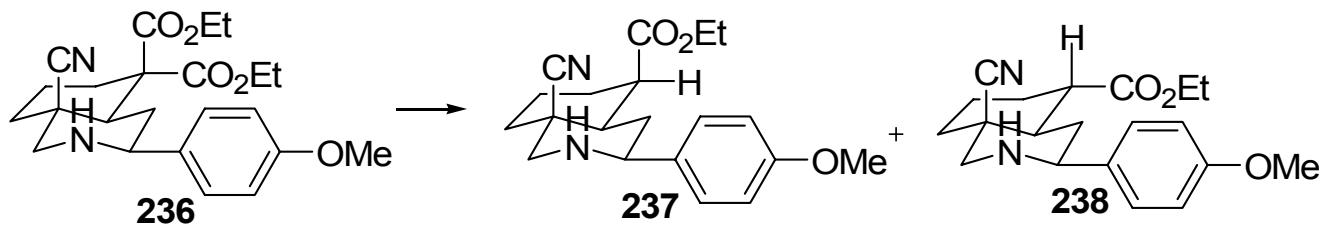

\subsubsection{Heterocyclic-1,1-dicarboxylic acid dialkyl diesters}

The deethoxycarbonylations of bis-carbethoxy - $\beta$-lactams under microwave irradiation have been studied. As an illustrative example, 239a and 239b using $\mathrm{LiCl}$ in DMF under microwave irradiation led to product $\mathbf{2 4 0}(50 \%){ }^{146 a, b, c}$

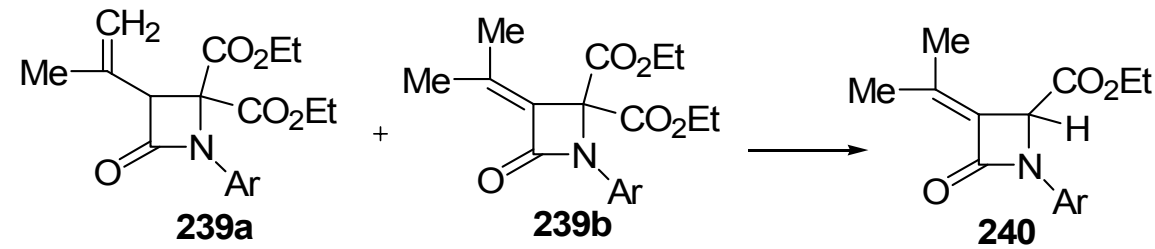

$$
\operatorname{Ar}=p=\text { Anisyl }
$$

The deethoxycarbonylation of 241 using $\mathrm{DMF}, \mathrm{LiCl}$, and water $\left(130^{\circ} \mathrm{C}, 3 \mathrm{~h}\right)$ led to azetidinone 242 (93\%, trans:cis 36.3:1), which was subsequently converted into a tryptase inhibitor BMS-262084 (99\%ee) for potential treatment of asthma. A study was also perfomed on the use of other N-protecting groups and the effect of water on the diasteroselectivity of the reaction. ${ }^{147}$<smiles>COC(=O)C1(C(C)=O)[C@H](CCCNC(=O)C(F)(F)F)C(=O)N1[Mg]</smiles><smiles>CC(=O)[C@H]1[C@@H](CCCNC(=O)C(F)(F)F)C(=O)N1O</smiles>

Treatment of azetidin-2-one $\mathbf{2 4 3}$ with $\mathrm{DMSO}, \mathrm{NaCl}$ and water (reflux, $4 \mathrm{~h}$ ) afforded predominantly cis-3-phenylthio-4-ethoxycarbonylazetidin-2-one (244) along with small amounts of the trans isomer, cis:trans ratio (12:1). ${ }^{148}$<smiles>CCOC(=O)C1(C(=O)OC)C(Sc2ccccc2)C(=O)N1[14CH](O)c1ccccc1</smiles>

243<smiles>CCOC(=O)[C@H]1[C@H](S[Pb]C)C(=O)N1[C@H](C)Oc1ccccc1</smiles>

244

The deethoxycarbonyations of several $\mathrm{N}$-aryl- and N-aralkyl-4-oxo-azetidine-2,2dicarboxylates were performed using $\mathrm{DMSO}, \mathrm{NaCl}$ and water $\left(170-180^{\circ} \mathrm{C}, 5 \mathrm{~h}\right)$. For example, 
treatment of $\mathbf{2 4 5}$ led to $\mathbf{2 4 6}$ (94\%). ${ }^{149}$ Other related dealkoxycarbonylations have been reported. ${ }^{150 \mathrm{a}, \mathrm{b}, \mathrm{c}}$
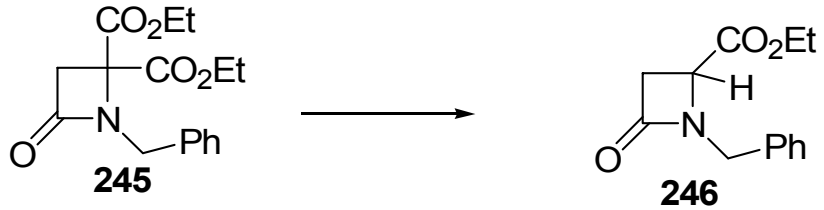

The deethoxycarbonylation of diethyl ester 257 using DMSO and $\mathrm{LiCl}$ under anhydrous conditions in the presence of molecular sieves and 2,6-di-tert-butyl-4-methylphenol $\left(140^{\circ} \mathrm{C}, 2 \mathrm{~h}\right)$ led to (2S,1'S)-258 and (2R,1'S)-259 (78\%) (diastereoisomeric ratio 2.7:1) which could be separated by column chromatography. These isomers were utilized in a synthesis of (S)azetidine-2-carboxylic acid. ${ }^{151}$

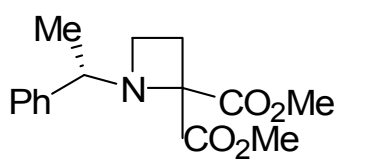

257<smiles>COC(=O)[C@H]1CCN1C(C)c1ccccc1</smiles>

258<smiles>COC(=O)[C@@H]1CCN1C(C)c1ccccc1</smiles>

259

The demethoxycarbonylation of $\mathbf{2 6 0}$ with $\mathrm{DMSO}, \mathrm{LiCl}$ and water $\left(165-170^{\circ} \mathrm{C}, 70 \mathrm{~min}\right)$ led predominantly to $\mathbf{2 6 1}(83 \%){ }^{152}$

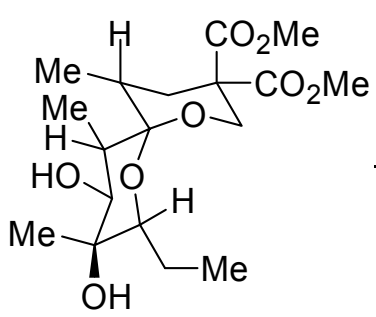

260

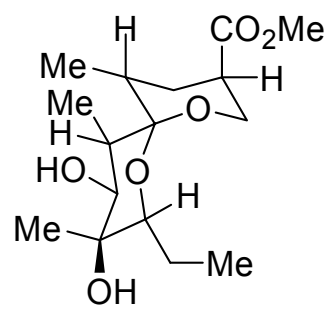

261

Treatment of $\mathbf{2 6 2}$ with DMSO, $\mathrm{LiCl}$ and water $\left(140-145^{\circ} \mathrm{C}, 4 \mathrm{~h}\right)$ afforded a mixture of 263 and 264 (80\%, ratio cis:trans $89: 11)$, which could be separated. ${ }^{153}$

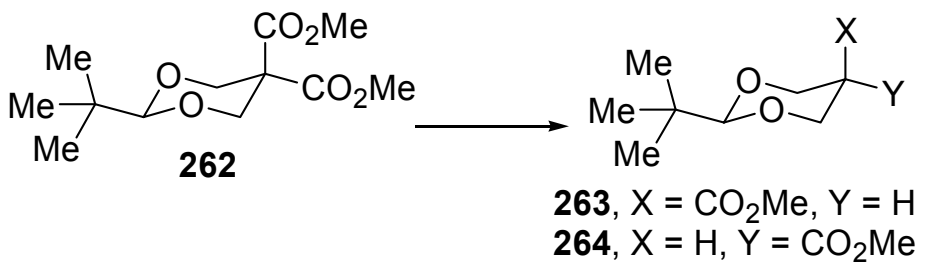

The diester 265 in DMSO, $\mathrm{NaCl}$ and water (reflux, $24 \mathrm{~h}$ ) led to the demethoxycarbonylation product $266(69 \%)$ with the ketal group intact. ${ }^{154 a, b}$ 

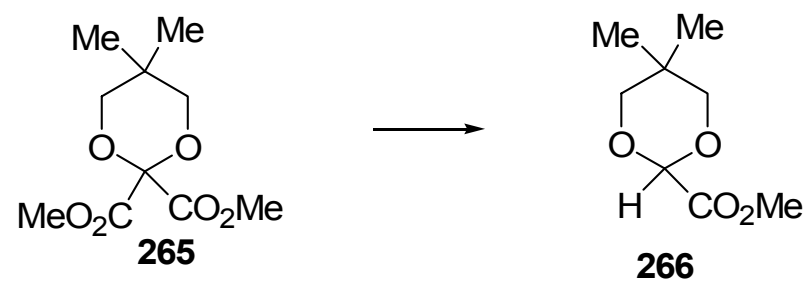

Upon treatment of the diester rac-267 with $\mathrm{DMSO}, \mathrm{NaCN}$ and water $\left(110^{\circ} \mathrm{C}, 20 \mathrm{~h}\right) \mathrm{a}$ diastereoisomeric mixture of rac-268 (6.7:1) was obtained. These diastereoisomers could be separated by chromatography to afford rac-268 as the major product. Chiral diester $\mathbf{2 6 7}$ ( $97 \%$ ee) led to enantiomer $\mathbf{2 6 8}$. $^{155}$
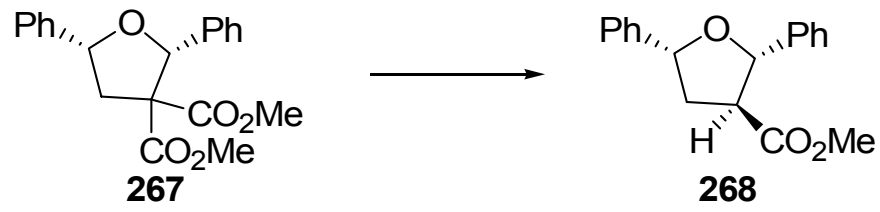

The demethoxycarbonylation of $\mathbf{2 6 9}$ with $\mathrm{DMSO}, \mathrm{LiCl}$ and water (reflux until no further gas evolution) led to 270a:270b (85\%) in a $4: 1$ ratio which could be separated by chromatography. ${ }^{156}$
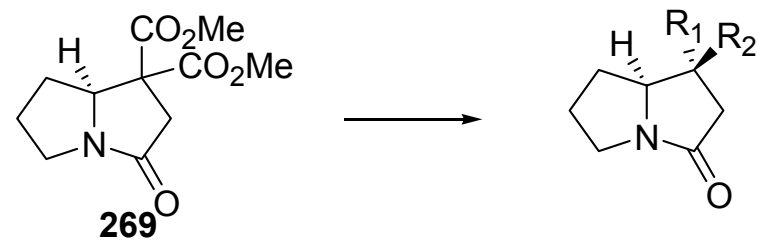

270a, $\mathrm{R}_{1}=\mathrm{CO}_{2} \mathrm{Me}, \mathrm{R}_{2}=\mathrm{H}$

270b, $\mathrm{R}_{1}=\mathrm{H}, \mathrm{R}_{2}=\mathrm{CO}_{2} \mathrm{Me}$

The pyrrolidinone $\mathbf{2 7 1}$ on treatment with $\mathrm{DMSO}, \mathrm{NaCl}$ and water led to $\mathbf{2 7 2}$. However it was found that treatment of $\mathbf{2 7 1}$ with $\mathrm{LiBr}$ in DMI (1,3-dimethyl-2-imidazolidinone) and water $\left(155^{\circ} \mathrm{C}\right)$ led to $272(64 \%)$ as an inseparable mixture of C-5 isomers ( ratio 1:1). ${ }^{157}$

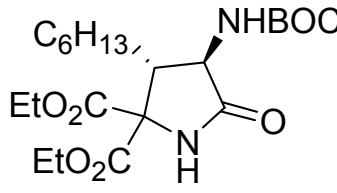

271<smiles>CCOC(=O)[C@H]1C[C@@H](NC(C)=O)C(=O)N1</smiles>

272

In routes leading to the preparation of tetrahydro- $\beta$-carboline analogues, the deethoxycarbonylation of $\mathbf{2 7 3}$ using DMSO, $\mathrm{LiCl}$ and water $\left(180^{\circ} \mathrm{C}, 7 \mathrm{~h}\right)$ led to a diastereoisomeric mixture of $\mathbf{2 7 4}$ (98\%) which could be separated by TLC. ${ }^{158}$ 


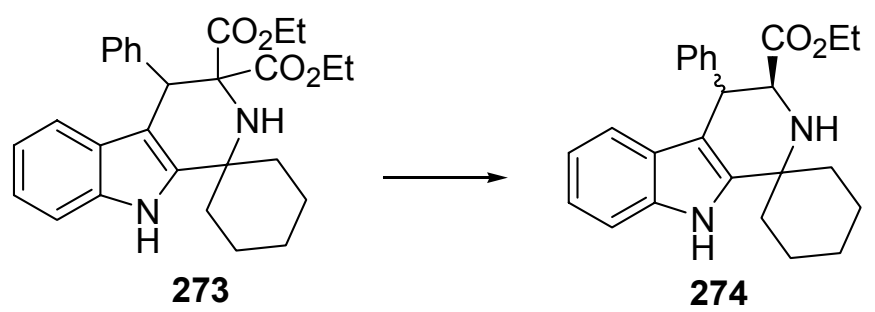

The deethoxycarbonylation of the silacyclopentane analogue 275 with DMSO, $\mathrm{NaCl}$ and water (no conditions reported ) led to monoester $276(90 \%){ }^{159}$

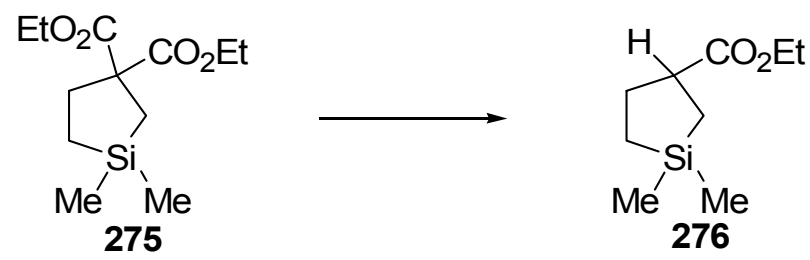

Treatment of 277 with $\mathrm{DMSO}, \mathrm{LiCl}$ and water $\left(170-180^{\circ} \mathrm{C}, 5 \mathrm{~h}\right)$ to $\mathbf{2 7 8}(96 \%)$ as a mixture mixture of diastereomeric esters used in a multi-step synthesis of vinblastine analogues. ${ }^{160}$<smiles>[R70]CC1(C(=O)OCC)CCC(=O)N2CCc3c([nH]c4ccccc34)C2CC(COCC)(C(=O)OCC)CC1</smiles>

The deethoxycarbonylations of several 3,4-dihydro- $\beta$-carbolines with DMSO, LiCl and water $\left(170^{\circ} \mathrm{C}, 7-9 \mathrm{~h}\right)$ led to the 5,6 and 7-acylamino- $\beta$-carbolines. As an illustrative example, analogue 279 led to $280(30 \%){ }^{161}$<smiles>C=Nc1cccc2[nH]c3c(c12)CC(OCC)(C(=O)OCC)N=C3</smiles>

279<smiles>CCOC(=O)c1cc2c(cn1)[nH]c1cccc(N)c12</smiles>

280

Treatment of racemic 281 with $\mathrm{DMSO}, \mathrm{NaCl}$ and water $\left(140^{\circ} \mathrm{C}, 20 \mathrm{~min}\right)$ led to racemic 282 (75\%) which was utilized in a synthesis of quinocarcinol. In the decarbomethoxylation process, about $10 \%$ of the endo-carbomethoxyl analogue was also obtained. ${ }^{162}$ 

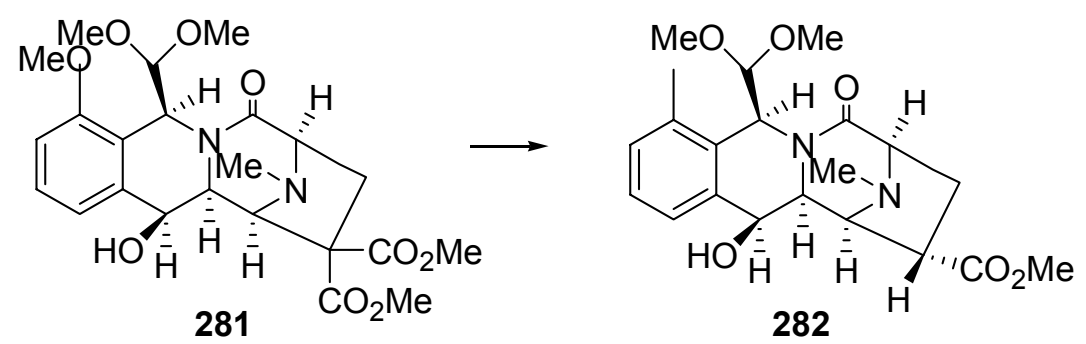

Treatment of 283 with DMSO, $\mathrm{NaCl}$ and water $\left(190^{\circ} \mathrm{C}, 25 \mathrm{~min}\right)$ led to the demethoxycarbonylated pyrimidine-5-carboxylate $284(21 \%){ }^{163}$

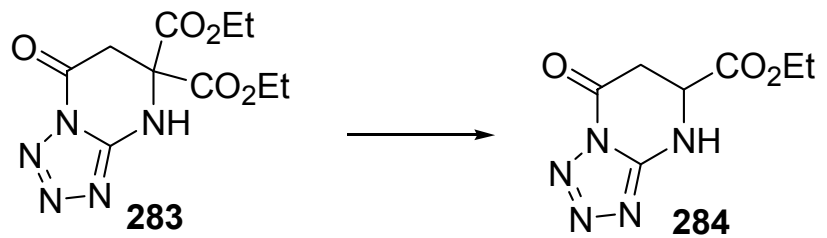

Diester 285 on treatment with DMF, $\mathrm{LiCl}$ and water $\left(110^{\circ} \mathrm{C}, 10 \mathrm{~h}\right)$ led to 286a and 286b which were separated by preparative tlc. Several other related systems were also dealkoxycarbonylated. ${ }^{164}$

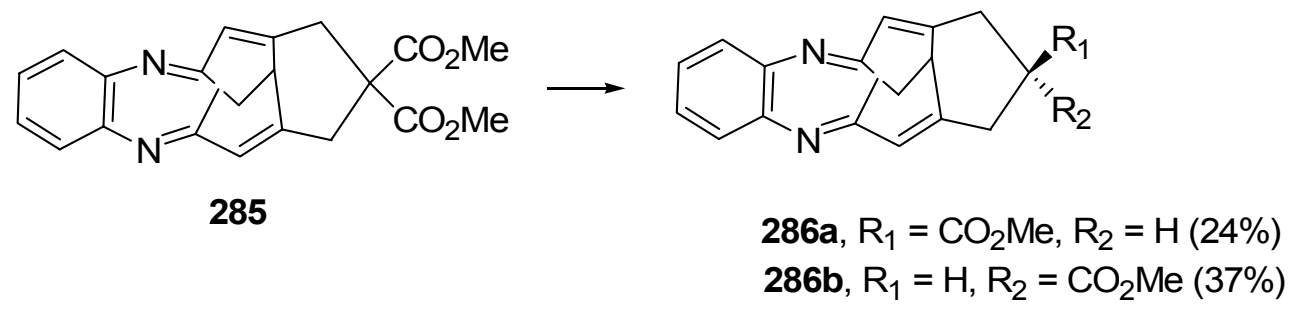

\subsubsection{2-Acylamino substituted analogues}

Treatment of $\mathbf{2 8 7}$ with DMSO and $\mathrm{LiCl}\left(120^{\circ} \mathrm{C}, 2 \mathrm{~h}\right)$ led to $\mathbf{2 8 8}(88 \%)$. On the other hand, the corresponding sulfoxide under similar conditions led to (Z)-ethyl-2-acetylamino-2-butenoate $(38 \%) .{ }^{165}$

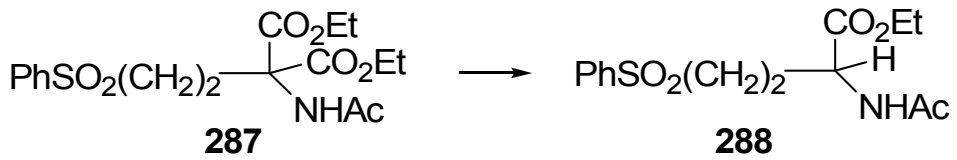

Treatment of the diester $\mathbf{2 8 9}$ with DMF, LiBr and water (reflux, 6 h) led to 290 (unspecified yield). It was also noted that the use of $\mathrm{LiBr}$ led to dramatic increases in the rate of reaction in comparison to other salts. This intermediate was utilized for the synthesis of several optically active unnatural amino acids. ${ }^{166}$ 


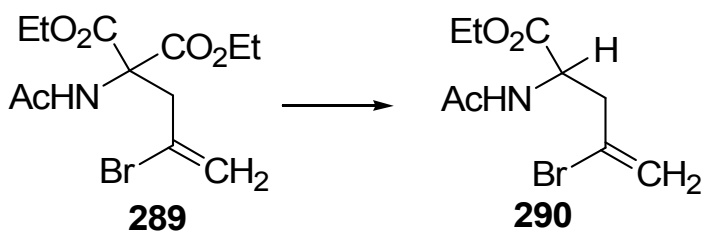

In pathways leading to 3 -deoxy sphingolipids, the diester 291 on treatment with DMSO, $\mathrm{NaCl}$ and water (reflux, $18 \mathrm{~h}$ ) led to intermediate $292(82 \%) .{ }^{167}$

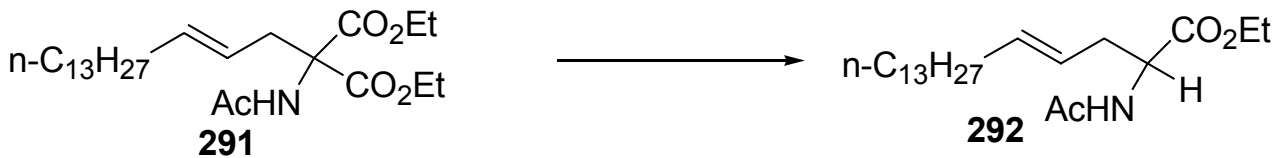

Treatment of 293 with $\mathrm{DMF}, \mathrm{NaCl}$ and water $\left(150^{\circ} \mathrm{C}, 4 \mathrm{~h}\right)$ led to $294(58 \%) .{ }^{168}$

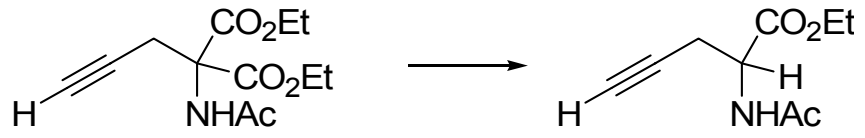

The decarboethoxylation of the stannyl substituted derivatives 295a and 295b on treatment with $\mathrm{DMF}, \mathrm{LiCl}$ and water (reflux, $12 \mathrm{~h}$ ) led to poor yields of $\mathbf{2 9 6 a}(4.2 \%)$ and $\mathbf{2 9 6 \mathbf { b }}(5.8 \%)$, respectively. ${ }^{169}$

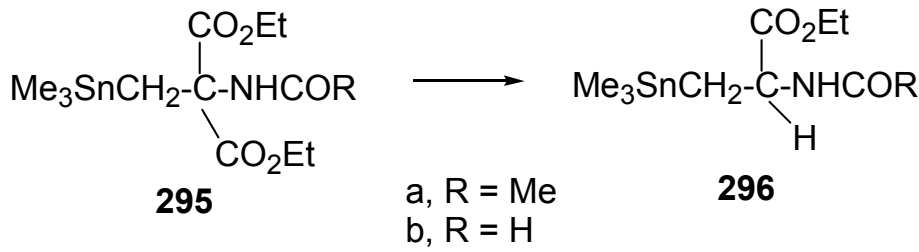

Treatment of 297 with DMSO, $\mathrm{NaCl}$ and water $\left(165^{\circ} \mathrm{C}, 8 \mathrm{~h}\right)$ led to the deethoxycarbonylation product $298(73 \%){ }^{170}$

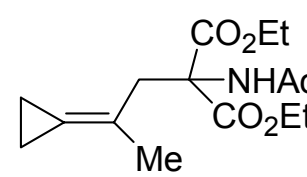

297

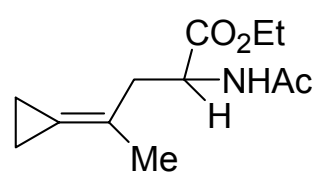

298

In synthetic pathways to carbazole-linked cyclic peptoids, treatment of 299 with DMSO, $\mathrm{LiCl}$ and water (reflux, $1.75 \mathrm{~h}$ ) led to intermediate 300 (70\%). ${ }^{171 \mathrm{a}, \mathrm{b}}$ 


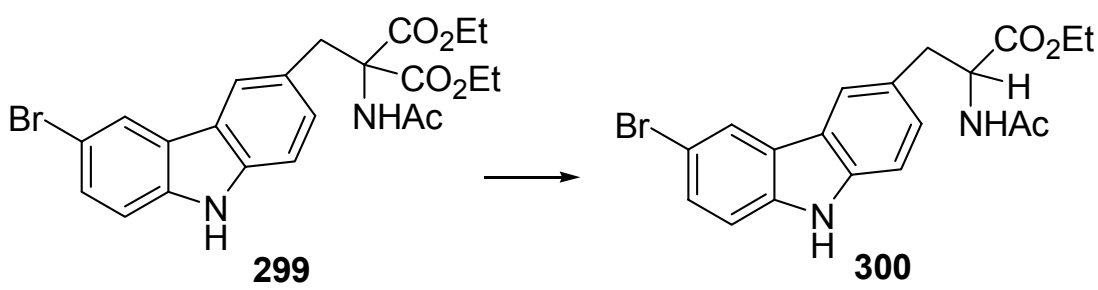

Treatment of $\mathbf{3 0 1}$ with DMSO, $\mathrm{NaCl}$ and water $\left(200^{\circ} \mathrm{C}, 15 \mathrm{~min}\right)$ led to $\mathbf{3 0 2}(53 \%) .{ }^{172}$

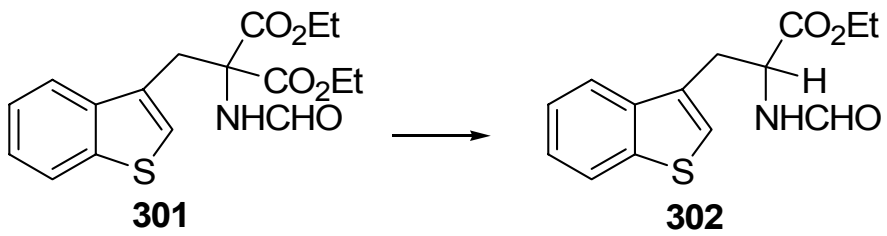

Treatment of the fluorinated analogue 303 with DMF, LiBr and water (reflux, 270 min) led to the deethoxycarbonylation product 304 (73\%), which was converted into optically active pazidotetrafluorophenylalanine and further evaluated as a potential photoaffinity reagent. ${ }^{173}$<smiles>CCOC(=O)C(N)(Cc1c(F)c(F)c(F)c(F)c1F)Cc1c(F)c(F)c(F)c(CC(NC(C)(C)C)(C(=O)OCC)C(=O)OCC)c1F</smiles>

Treatment of the substituted isoxazole 305 with DMSO, $\mathrm{NaCl}$ and water $\left(160^{\circ} \mathrm{C}, 7 \mathrm{~h}\right)$ led to mono ester 306 (78\%). Further elaboration by a $\alpha$-chymotrypsin resolution led to the corresponding amino acid. ${ }^{174}$<smiles>CCOC(=O)NC(Cc1conc1O[SbH3])(OCC)C(=O)OCC</smiles>

305<smiles>CCOC(=O)C(C)(N)Cc1conc1OCC</smiles>

306

Treatment of $\mathbf{3 0 7}$ with $\mathrm{LiCl}$ or $\mathrm{LiBr}$ in $\mathrm{DMSO}$ and water $\left(120^{\circ} \mathrm{C}, 2 \mathrm{~h}\right)$ led only to the deacylation products along with the acetamido substituted diethyl malonate. If $\mathbf{3 0 7}$ is heated with DMSO and water ( 2 eq) (reflux, 2 h) 308 (62\%) was obtained and a mechanism has been proposed. $^{175}$ 
<smiles>CCOC(=O)C(NC(=O)c1ccccc1)(C(=O)OCC)C(=O)c1ccccc1</smiles>

307

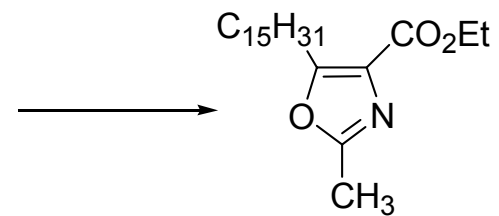

308

\subsubsection{Aryl-heteroaryl}

The extended malonate system on treatment with DMSO and 3 eq of $\mathrm{NaCN}\left(170-180^{\circ} \mathrm{C}, 1-2 \mathrm{~h}\right)$ led to decarbomethoxylation and ester cleavage of the $\mathrm{p}-\mathrm{CO}_{2} \mathrm{Me}$ group to yield the 2,4-diamino10-alkyl-8,10-dideazapteric acid. ${ }^{176,177}$ For example, under these conditions, the methyl substituted derivative $\mathbf{3 0 9}$ led to $\mathbf{3 1 0}(96 \%) .{ }^{176}$<smiles>CC(=O)c1ccc(C(C)(Cc2ccc3nc(N)nc(N)c3n2)C(C)=O)cc1</smiles>

309<smiles>CC(Cc1ccc2nc(N)nc(N)c2n1)c1ccc(C(=O)O)cc1</smiles>

310

\subsubsection{Bis-cyclic malonic ester}

Treatment of the tetra ester 311 under Krapcho's conditions (not specified) led to cis,cis-3,8cyclodecadiene-1,1,6,6-tetracarboxylate (312). ${ }^{178}$

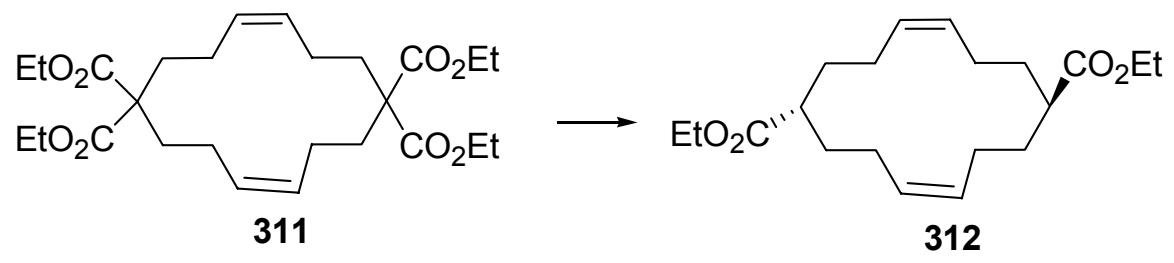

\subsubsection{Substituted $\alpha$-difluorobromomethyl malonate}

The conversion of malonic esters to esters holding an $\alpha-\mathrm{CF}_{3}$ group has been accomplished by a dealkoxycarbonylation-fluoridation route. Treatment of $\alpha$-bromodifluoromethyl substituted malonates 313 with $\mathrm{KF}$ in dry DMSO $\left(150^{\circ} \mathrm{C}\right)$ led to the $\alpha-\mathrm{CF}_{3}$ substituted esters 314 . Low boiling products were isolated by distillation from the reaction mixture and the higher boiling esters by dilution of the reaction mixture with water and extraction into ether. ${ }^{179 a, b}$

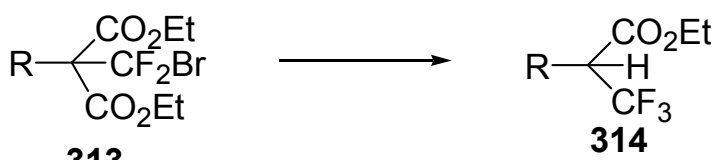

313

$$
\mathrm{R}=\mathrm{Me}, \mathrm{Et}, \mathrm{n}-\mathrm{Pr}, \mathrm{n}-\mathrm{Bu}(35-61 \%)
$$




\subsubsection{Trimethyl methanetricarboxylate}

Treatment of 315 with DMSO and $\mathrm{KCN}(2$ eq $)\left(90^{\circ} \mathrm{C}, 0.5 \mathrm{~h}\right)$ led the monodemethoxycarbonylation product $316(63 \%)$. A similar procedure using the triethyl ester led to the diethyl ester. ${ }^{180}$

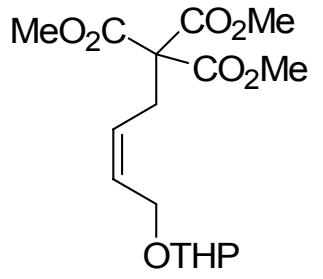

315

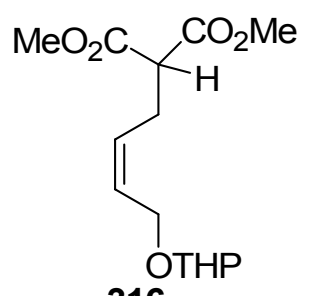

316

Some additional illustrative examples are tabulated in Table 2.

\subsubsection{Dealkoxycarbonylation-eliminations}

The demethoxycarbonylation of $\mathbf{3 1 7}$ on heating in DMSO (reflux, $2 \mathrm{~h}$ ) led to the corresponding ethyl-2-benzofuran carboxylate 318 (75-80\%), used in the preparation of analogues tested for histamine $\mathrm{H}_{2}$ receptor antagonist activity. ${ }^{200}$<smiles>CCOC(=O)C(OCC)(OCC)C(O)c1cc(C)cc(CN(C)[In])c1O</smiles><smiles>CCOC(=O)c1cc2cc(C)cc(CN(C)C)c2o1</smiles>

Treatment of 319 with DMSO, $\mathrm{LiCl}$ and water $\left(165^{\circ} \mathrm{C}, 1 \mathrm{~h}\right)$ led to the benzofuran derivative $320(86 \%) .{ }^{201 a}$ A related example with a different substitution pattern in the aromatic ring has also been reported. ${ }^{201 \mathrm{~b}}$<smiles>CCOC(=O)C1(C(=O)OCC)Oc2c(C)c(OC)cc(OC)c2C1O</smiles><smiles>CCOC(=O)c1cc2c(OC)cc(OC)c(C)c2o1</smiles> 
Table 2. Dealkoxycarbonylations of disubstituted malonate esters

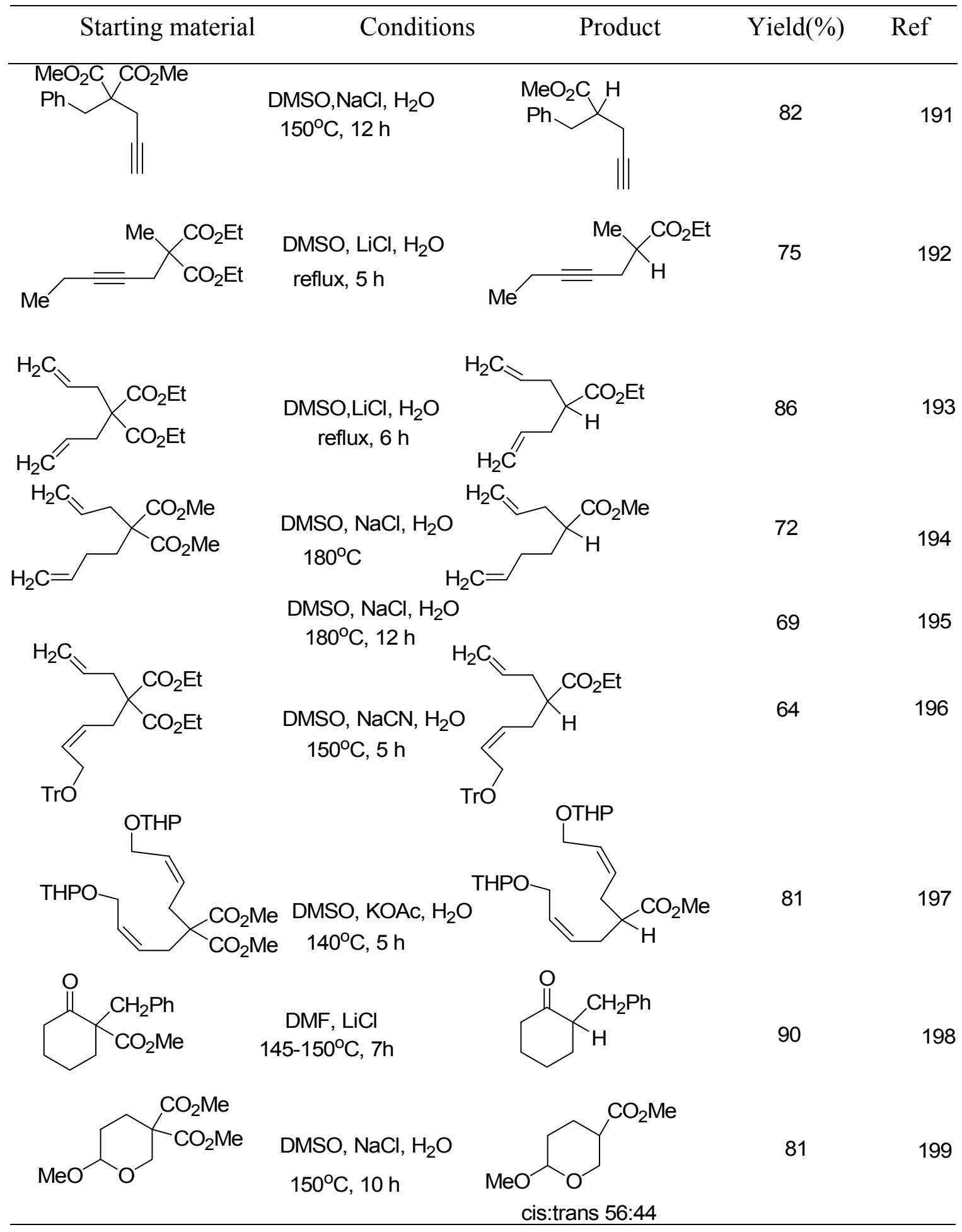

Treatment of a diastereoisomer mixture of $(12 \mathrm{R}, 12 \mathrm{~S}) 321$ with $\mathrm{DMSO}, \mathrm{NaCl}$ and water (110$\left.160^{\circ} \mathrm{C}, 3 \mathrm{~h}\right)$ and $160^{\circ} \mathrm{C}(0.5 \mathrm{~h})$ led to the $\beta$-elimination of the acetoxy group to afford $\mathbf{3 2 2}$ 
(1R,3R,8R,9R) (47\%), along with some recovered starting material, which could be recycled. This derivative was used in a synthetic study of routes to the trichothecene sesquiterpenes. ${ }^{202}$

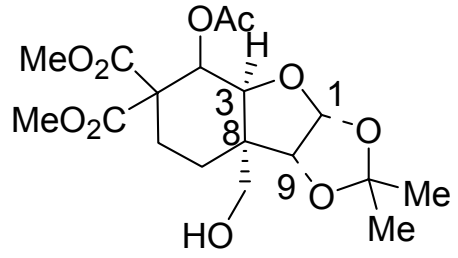

321

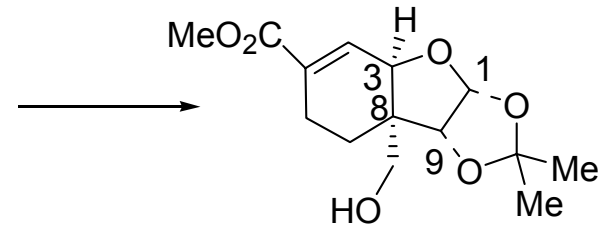

322

The decarbomethoxylation of $\mathbf{3 2 3}$ using DMSO, $\mathrm{NaCl}$ and water $\left(160^{\circ} \mathrm{C}, 4 \mathrm{~h}\right)$ led to $\beta$ elimination of the $\mathrm{OH}$ group to form the enantiomerically pure $\alpha, \beta$-unsaturated ester 324 (80\%). This intermediate could not be converted into enantiomerically pure 2 -oxospiroalkanes. ${ }^{203}$<smiles>COC(=O)C1(OC)CCC2(C3OC(C)(C)OC3O[C@H]2C2COC(C)(C)O2)C1O</smiles>

323<smiles>COC(=O)C1=CC2(CC1)C1OC(C)(C)OC1O[C@H]2C1COC(C)(C)O1</smiles>

324

A convenient synthesis of 2-alkenoic esters involved treatment of numerous $\beta$-substituted derivatives with solvents such as DMSO, DMF or HMPT and salts such as $\mathrm{NaBr}$ or $\mathrm{LiCl}$ $\left(130^{\circ} \mathrm{C}, 5 \mathrm{~h}\right)$. For example, treatment of $\mathbf{3 2 5}$ with $\mathrm{HMPT}, \mathrm{NaBr}$ at $135-140^{\circ} \mathrm{C}$ for $5 \mathrm{~h}$ gave $\mathbf{3 2 6}$ $(86 \%)$ with an $\mathrm{E} / \mathrm{Z}$ ratio of $88: 12^{204,205}$

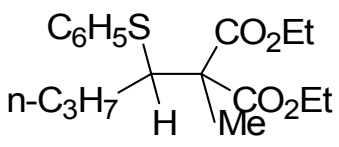

325

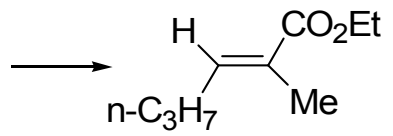

326

The demethoxycarbonylation of 327 using DMF and LiI $\left(160^{\circ} \mathrm{C}\right)$ led to 328-(Z) $(14 \%)$ and 329-(E) (52\%), respectively. ${ }^{206}$<smiles>COC(C)(C(C)F)C(C)(C)C(C)(F)F</smiles>

327<smiles>COC(=O)c1csc(NC=O)n1</smiles>

328-(Z)<smiles>CC(=O)C(=CF)c1csc(NC=O)n1</smiles>

329-(E) 


\subsubsection{Substituted heterocyclic system}

Treatment of the imidazo[1,2a]pyridine 330 with DMSO, $\mathrm{NaCl}$ and water $\left(150^{\circ} \mathrm{C}, 5 \mathrm{~h}\right)$ led regioselectively to the 6-methoxycarbonyl derivative $331(61 \%){ }^{207}$<smiles>COC(=O)c1c(-c2ccccc2)cc2nccn2c1C(C)=O</smiles>

330<smiles>COC(=O)c1cn2ccnc2cc1-c1ccccc1</smiles>

331

\subsubsection{Cinnamic esters: from arylmethylene-propanedioic acid dimethyl esters}

The dealkoxycarbonylations of arylmethylene-propanedioic acid dimethyl esters (332) in DMSO-NaCl- $\mathrm{H}_{2} \mathrm{O}$ (and in DMF with other salts) have been studied. In general, the esters led predominantly to the trans-cinnamic esters $(\mathbf{3 3 3}){ }^{208 a, b}$<smiles>[R]C(=O)C(=Cc1cccc([R])c1)C(=O)O[Na]</smiles>

332

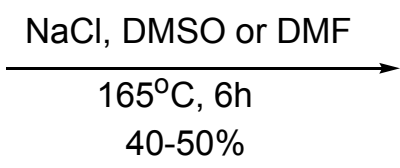

$40-50 \%$<smiles>[R]c1ccccc1/C=C/C(C)=O</smiles>

333

$$
\mathrm{R}=\mathrm{H}, \mathrm{o}-\mathrm{Me}, \mathrm{o}-\mathrm{OMe}, \mathrm{o}-\mathrm{OCH}\left(\mathrm{CH}_{3}\right)_{2}, \mathrm{p}-\mathrm{Me}, \mathrm{p}-\mathrm{OMe}, \mathrm{p}-\mathrm{NO}_{2}
$$

\section{Conclusions}

The dealkoxycarbonylation procedure is a useful synthetic method for the formal replacement of a $\mathrm{CO}_{2} \mathrm{R}$ moiety with a $\mathrm{H}$ atom and should continue to find numerous applications in synthetic strategies.

\section{References}

1. Krapcho, A. P. Synthesis 1982, 805.

2. Krapcho, A. P. Synthesis 1982, 893.

3. Hassner, A.; Stumer, C. In Organic Synthesis Based on Name Reactions; Pergamon: New York, $2^{\text {nd }}$ Edn., 2002, Vol. 22, p 207.

4. The Merck Index , $13^{\text {th }}$ Edn., Merck \& Co., Inc.: Whitehouse Station, NJ 2001, ONR-60.

5. Li, J. L. In Name Reactions A Collection of Detailed Reaction Mechanisms; SpringerVerlag: Berlin, 2002, p 204.

6. Mundy, B. P.; Ellerd, M. G.; Favaloro, F. G. Jr. In Name Reactions and Reagents in Organic Synthesis; $2^{\text {nd }}$ Edn., Wiley-Interscience, 2005; p 380. 
7. Kurti, L.; Czako, B.I. In Strategic Applications of Named Reactions in Organic Synthesis; Elsevier, 2005; p 252.

8. Krapcho, A. P. In Science of Synthesis; Houben-Weyl Methods of Molecular Transformations; Majewski, M. and Snieckus,V. Eds., Georg Thieme: Stuttgart, 2005, Vol. 8b, pp 925-1010.

9. Yannai, M. B.; Rappoport, Z. J. Org. Chem. 1996, 61, 3553.

10. Gilligan, P. J.; Krenitsky, P. J. Tetrahedron Lett. 1994, 35, 3441.

11. Saitoh, A.; Achiwa, K.; Morimoto, T. Tetrahedron: Asymmetry 1998, 9, 741.

12. Perrard, T.; Plaquevent, J.-C.; Desmurs, J.-R.; Hebrault, D. Org. Lett. 2000, 2, 2959.

13. (a) Loupy, A.; Pigeon, P.; Ramdani, M. Jacquault J. Chem. Res. (S) 1993, 36. Loupy, A.; Petit, A.; Hamelin, J.; Texier-Boullet, F.; Jacquault, P.; Methe, D. Synthesis 1998, 11213.

14. Curran, D. P.; Zhang, Q. Adv. Synth. Catal. 2003, 345, 329.

15. Kim, D. H. J. Heterocyclic Chem. 1981, 18, 1393.

16. Sharma, S. K.; Wu, A. D.; Chandramouli, N.; Fotsch, C.; Kardash, G.; Bair, K. W. J. Peptide Res. 1999, 53, 501.

17. Kim, J.; Matsuyama, S.; Suzuki, T. J. Label. Compd. Radiopharm. 2004, 47, 921.

18. Hernandez, L.; Casanova, E.; Loupy, A.; Petit, A. J. Label. Compd. Radiopharm. 2003, 46, 151.

19. Hoekstra, M. S.; Sobieray, D. M.; Schwindt, M. A.; Mulhern, T. A.; Grote, T. M.; Huckabee, B. K.; Hendrickson, V. S.; Franklin, L. C.; Granger, E. J.; Karrick, G. L. Org. Process. Res. Dev. 1997, 1, 26.

20. Barbero, A.; Blakemore, D. C.; Fleming, I.; Wesley, R. N. J. Chem. Soc. Perkin Trans. 1 1997, 1329.

21. Bringmann, G.; Geuder, T. Synthesis 1991, 829.

22. Golding, B. T.; Griffin, A. L.; Robinson, D. H. Tetrahedron Lett. 1993, 34, 6459.

23. Evans, D. A.; Rovis, T.; Kozlowski, M. C.; Downey, C. W.; Tedrow, J. S. J. Am. Chem. Soc. 2000, $122,9134$.

24. Sibi, M. P.; Chen., J. Org. Lett. 2002, 4, 2933.

25. Cane, D. E.; Tandon, M. Tetrahedron Lett. 1994, 35, 5355.

26. Mori, M.; Washioka, Y.; Urayama, T.; Yoshiura, K.; Chiba, K.; Ban, Y. J. Org. Chem. 1983, 48, 4058.

27. Ono, N.; Hamamoto, I.; Kaji, A. Synthesis 1985, 950.

28. (a) Fiaud, J. C.; Legros, J. Y. J. Organometal. Chem. 1989, 370, 383. (b) Fiaud, J. C.; Legros, J. Y. Tetrahedron Lett. 1988, 29, 2959.

29. Vig, O. P.; Sharma, M. L.; Sabharwal, A.; Vohra, N. Indian J. Chem. 1986, 25B, 1042

30. Ogasawara, M.; Nagano, T.; Hayashi, T. J. Org. Chem. 2005, 70, 5764.

31. Pornet, J.; Kolani, N'B., Mesnard, D.; Miginiac, L.; Jaworski, K. J. Organomet. Chem. 1982, 236, 177.

32. Tietze, L. F.; Ruther, M. Chem. Ber. 1990, 123, 1387. 
33. Meyers, A. I.; Bienz, S. J. Org. Chem. 1990, 55, 791.

34. Gustavsson, A.- L.; Larsson, M. C.; Hansson, B. S.; Liljefors, T. Bioorg. Med. Chem. 1997, 5,2173

35. Larsen, S. D.; Spilman, C. H.; Yagi, Y.; Dinh, D. M.; Hart, K. L.; Hess, G. F. J. Med. Chem. 1994, 37, 2343.

36. Tzvetkov, N. T.; Schmoldt, P.; Neumann, B.; Stammler, H.-G.; Mattay, J. Tetrahedron: Asymmetry 2006, 17, 993.

37. Tietze, L. F.; Beifuss, U.; Antel, J.; Sheldrick, C. M. Angew. Chem. Int. Ed. Engl. 1998, 27, 703.

38. (a) Bergner, E. J.; Helmchen, G. Eur. J. Org. Chem. 2000, 419. (b) Fernandez-Mateos, A.; Alonso, J. J. P.; Gonzalez, R. R. Tetrahedron 1999, 55, 847. (c) Yoo, B.; Curran, D. P. Bull. Korean Chem. Soc. 1996, 17, 1009. (d) Dzieduszycka, M.; Smulkowski, M.; Borowski, E. Pol. J. Chem. 1982, 56, 1569.

39. Jonasson, C.; Ronn, M.; Backvall, J.-E. J. Org. Chem. 2000, 65, 2122.

40. Pearson, A. J.; Ray, T. Tetrahedron 1985, 41, 5765.

41. Fernandez-Mateos, A.; Coca, G. P.; Gonzalez, R. R.; Hernandez, C. T. Tetrahedron 1996, $52,4817$.

42. Fleming, I.; Waterson, D. J. Chem. Soc., Perkin Trans. 1 1984, 1809.

43. Pearson, A. J.; Kole, S. L.; Ray, T. J. Am. Chem. Soc. 1984, 106, 6060.

44. Maehr, H.; Uskokovic, M. R. Eur. J. Org. Chem. 2004, 1703.

45. Kato, N.; Kataoka, H.; Ohbuchi, S.; Tanaka, S.; Takeshita, H. J. Chem. Soc. Chem. Commun. 1988, 354.

46. Kutner, A.; Chodynski, M.; Masnyk, M.; Wicha, J. Org. Process Res. Dev. 1998, 2, 290

47. Pouzar, V.; Karaszova, L; Havel, M. Collect. Czech. Chem. Commun. 1987, 52, 2735

48. Alexakis, A.; Benhaim, C. Tetrahedron:Asymmetry 2001, 12, 1151.

49. Belda, O.; Lundgren, S.; Moberg, C. Org. Lett. 2003, 5, 2275.

50. Kinoshita, T.; Okamoto, K.; Clardy, J. Synthesis 1985, 402.

51. Owings, F. F.; Fox, M.; Kowalski, C. J.; Baine, N. H. J. Org. Chem. 1991, 56, 1963.

52. Mehta, N. B.; Musso, D. L. J. Pharmaceut. Sci. 1986, 75, 410.

53. Henry, G. E.; Jacobs, H. Tetrahedron 2001, 57, 5335.

54. Quallich, G. J.; Morrissey, P. M. Synthesis 1993, 51.

55. Sakakibarra, M.; Mizumoto, T.; Watanabe, Y.; Toru, T.; Ueno, Y. Bull. Chem.. Soc. Jpn. 1992, 65, 1794.

56. Mayer, J. M.; Testa, B. Helv. Chim. Acta 1982, 65, 1868.

57. Schleich, S.; Helmchen, G. Eur. J. Org. Chem. 1999, 2515.

58. Kuehne, M. E.; Xu, F. J. Org. Chem. 1997, 62, 7950.

59. MacDowell, D. W. H.; Purpura, J. M. J. Org. Chem. 1986, 51, 183.

60. Pearson, A. J.; Rees, D. C. J. Am. Chem. Soc. 1982, 104, 1118.

61. (a) Ohtake, N.; Imai, Y.; Ushijima, R. Tetrahedron 1998, 54, 2423. (b) Sato, H.; Sakoh, H.; Hashihayata, T.; Imamura, H.; Ohtake, N.; Shimizu, A.; Sugimoto, Y.; Sakuraba, S.; 
Bamba-Nagamo, R.; Yamada, K.; Hashizume, T.; Morishima, H. Bioorg. Med. Chem. 2002, 10, 1595.

62. Suzuki, Y.; Knoche, H. W.; Daly, J. M. Bioorg. Chem. 1982, 11, 300.

63. Lassaletta, J. M.; Vazquez, J.; Prieto, A.; Fernandez, R.; Raabe. G.; Enders, D. J. Org. Chem. 2003, 68, 2698.

64. Zhu, Q.; Qiao, L. Wu, Y.; Wu, Y.-L. J. Org. Chem. 2001, 66, 2692.

65. Tadano, K.-I.; Isshiki, Y.; Minami, M.; Ogawa, S. J. Org. Chem. 1993, 58, 6266.

66. Fleet, G. W. J.; Shing, T. K. M. J. Chem. Soc. Chem. Commun. 1984, 835.

67. Doboszewski, B.; Herdewijn, P. A. M. Nucleosides \& Nucleotides 1996, 15, 1495.

68. Matsuda, F.; Terashina, S. Tetrahedron 1988, 44, 4721.

69. Ando, K.; Yasuda, K.; Tomioka, K.; Koga, K. J. Chem. Soc. Perkin Trans. 1 1994, 277.

70. Corey, E. J.; Su, W.-G. Tetrahedron Lett. 1990, 31, 2089.

71. Ley, S. V.; Somovilla, A. A.; Broughton, H. B.; Craig, D.; Slawin, A. M. Z.; Toogood, P. L.; Williams, D. J. Tetrahedron 1989, 45, 2143.

72. Dutta, A. K.; Ryan, W.; Thomas, B. F.; Singer, M.; Compton, D. R.; Martin, B. R.; Razdan, R. K. Bioorg. Med. Chem. 1997, 5, 1591.

73. Sime, J. T.; Barnes, R. D.; Elson, S. W.; Jarvest, R. L.; O’Toole, K. J. J. Chem. Soc. Perkin Trans. 1 1992, 1653.

74. Rao, H. S. P.; Bharathi, B.; Jeyalakshmi, K. Indian J. Chem. 1997, 36B, 557.

75. Crich, D.; Fortt, S. M. Tetrahedron 1989, 45, 6581.

76. Pigou, P. E. J. Org. Chem. 1989, 54, 4943.

77. Chenevert, R.; Desjardins, M. Tetrahedron Lett. 1991, 32, 4249.

78. Alvarez, E.; Cuvigny, C.; Herve du Penhoat, C.; Julia, M. Tetrahedron 1988, 44, 119.

79. Verma, R.; Mithran, S.; Ghosh, S. K. J. Chem. Soc Perkin Trans. 1 1999, 257

80. Prowotorow, I.; Wicha, J.; Mikami, K. Synthesis 2001, 145.

81. Morimoto, Y.; Shirahama, H. Tetrahedron 1996, 52, 10631.

82. Miftakhov, M. S.; Yumagulova, S. A.; Ibatullin, U. G.; Akhmetvaleev, R. R. Russ. J. Org. Chem. (Engl. Transl) 1996, 32, 800.

83. Kato, S.; Morie, T.; Hino, K.; Kon, T.; Naruto, S.; Yoshida, N.; Karasawa, T.; Matsumoto, J.-I. J. Med. Chem. 1990, 33, 1406.

84. Sharma, G. V. M.; Shekharam, T.; Upender, V. Tetrahedron 1990, 46, 5665.

85. Yadav, J. S.; Rao, E. S.; Rao, V. S. Synth. Commun. 1989, 19, 705.

86. Vig, O.P.; Bari, S. S.; Sattar, M. A.; Sharma, S. Indian J. Chem. 1989, 28B, 617.

87. Miyazaki, H.; Nakamura, N.; Ito, T.; Sada, T.; Oshima, T.; Koike, H. Chem. Pharm Bull. 1989, 37, 2391.

88. Dyer, U. C.; Robinson, J. A. J. Chem. Soc. Perkin Trans. 1 1988, 53.

89. Yang, Y.-L; Manna, S.; Falck, J. R.; J. Am. Chem. Soc. 1984, 106, 3811.

90. Vig, O. P.; Sharma, M. L.; Taneja, K. C.; Malik, N. Indian J. Chem. 1981, 20B, 863.

91. Bougeois, J.-L.; Stella, L.; Surzur, J.-M. Tetrahedron Lett. 1981, 22, 61.

92. Vig, O. P.; Sharma, M. L.; Verma, N. K. Indian J. Chem. 1982, 21 B, 384. 
93. Vig, O. P.; Sharma, M. L.; Kumari, S.; Rani, V. Indian J. Chem. 1985, 24B, 675.

94. Vig, O. P.; Sharma, M. L.; Gauba, R. Indian J. Chem. 1985, $24 B, 313$.

95. Oehlschlager, A. C.; Wong, J. W.; Verigin, V. G.; Pierce, H. D. Jr. J. Org. Chem. 1983, 48, 5008.

96. Breault, G. A.; Hunter, C. A.; Mayers, P. C. J. Am. Chem. Soc. 1998, 120, 3402.

97. Bauer, H.; Stier, F.; Petry, C.; Knorr, A.; Stadler, C.; Staab, H. A. Eur. J. Org. Chem. 2001, 3255.

98. Staub, H. A.; Riegler, N.; Diederich, F.; Krieger, C. Schweitzer, Chem. Ber. 1984, 117, 246.

99. Reingold, I. D.; Drake, J. Tetrahedron Lett. 1989, 30, 1921.

100.Reingold, I. D.; Beckmann, G.; Grannas, A. M.; Brunette, S. R.; Williams, B. D.; Lovell, S.; Kahr, B. E. Org. Prep. Proc. Int. 1998, 30, 235.

101.Fakhri, S. A.; Yousefi, B. H. Tetrahedron 2000, 56, 8301.

102.Ganesh, K. N.; Sanders, J. K. M. J. Chem. Soc. Perkin Trans. 1 1982, 1611.

103.(a) Gotti, A.; Brandi, A.; Danza, G.; Guarna, A.; Donati, D.; De Sarlo, F. J. Chem. Soc. Perkin Trans. 1 1989, 1253.(b) Brandi, A.; Cordero, F. M.; De Sarlo, F.; Goti, A.; Guarna, A. Synlett 1993, 1. (c) Zorn, C.; Anichini, B.; Goti, A.; Brandi, A.; Kozhushkov, S. I.; de Meijere, A.; Citti, L. J. Org. Chem. 1999, 64, 7846.

104.Holden, M. S.; Bedell, B. L.; Snader, B. M.; Bui, Vu P. J. Organometal. Chem. 2000, 613, 263.

105.(a) Gurjar, M.; Reddy, D. S.; Murugaiah, A.; Murugaiah, S. Synthesis 2000, 1659. (b) Gurjar, M. K.; Murugaiah, A. M. S.; Reddy, D. S.; Chorghade, M. S. Org. Process Res. Dev. 2003, 7, 309.

106.Baarschers, W. H.; Li, M. A. Can. J. Chem. 1983, 61, 1784.

107.Hayes, R. N.; Bowie, J. H. J. Chem. Soc. Perkin Trans. 2 1986, 1827.

108. Tetenyi, P. Jr.; React. Funct. Polym. 2002, 50, 117.

109.Chatterjee, M. N.; Kay, E. R.; Leigh, D. A. J. Am. Chem. Soc. 2006, 128, 4058.

110.Avdagic, A.; Cotarca, L.; Ruzic, K. S.; Gelo, M.; Sunjic, V. Biocatalysis 1994, 9, 49.

111. Crump, R. A. N. C. : Fleming, I.; Hill, J. H. M.; Parker, D.; Reddy, N. L.; Waterson, D. J. Chem. Soc. Perkin Trans. 1 1992, 3277.

112.West, F. G.; Glaeske, K. W.; Naidu, B. N. Synthesis 1993, 977.

113. Sangaiah, R.; Gold, A. J. Org. Chem. 1987, 52, 3205.

114.(a) Burtin, G.; Pellissier, H.; Santelli, M. Tetrahedron 1998, 54, $8065 . \quad$ (b) Burtin, G.; Pellissier, H.; Santelli, M. Tetrahedron 1998, 54, 4913. (c) Michellys, P.-Y.; Maurin, P.; Toupet, L.; Pellissier, H.; Santelli, M. J. Org. Chem. 2001, 66, 115.

115. Yamanaka, E.; Narushima, M.; Inukai, K.; Sakai, S.-I. Chem.. Pharm. Bull. 1986, 34, 77.

116.Lebegue, N.; Charrier, G.; Carato, P.; Yous, S.; Berthelot, P. Tetrahedron Lett. 2004, 45, 9509.

117.Honda, T.; Ishige, H.; Araki, J.; Akimoto, S.; Hirayama, K.; Tsubuki, M. Tetrahedron 1992, $48,79$.

118. Kreiselmeier, G.; Fohlisch, B. Tetrahedron Lett. 2000, 41, 1375. 
119.Krief, A.; Froidbise, A. Tetrahedron 2004, 60, 7637.

120.(a) Bernard, A. M.; Paolo, P. P. Synth. Commun. 1992, 22, 2789. (b) Bernard, A. M.; Piras, P. P.; Cocco, M. T.; Congiu, C.; Onnis, V. Gazz. Chim. Ital. 1997, 127, 189. ' Bernard, A. M.; Cerioni, G.; Piras, P. P.; Seu, G. Synthesis 1990, 871.

121.Piras, P. P.; Stirling, J. M. J. Chem. Soc. Perkin Trans . 2 1987, 1265.

122. Michelet, V. Genet, J.-P. Bull. Soc. Chim. Fr, 1996, 881.

123. Ahmad, S.; Doweyko, L. M.; Dugar, S.; Grazier, N.; Ngu, K.; Wu, S. C.; Yost, K. J.; Chen, B.-C; Gougoutas, J. Z.; DiMarco, J. D.; Lan, S.-J.; Gavin, B. J.; Chen, A. Y.; Dorso, C. R.; Serafino, R.; Kirby, M.; Atwal, K. S. J. Med Chem. 2001, 44, 3302.

124. Hanzawa, Y.; Ishizawa, S.; Kobayashi, Y. Chem. Pharm Bull. 1988, 36, 4209.

125.Krief, A.; Devos, M. J.; Sevrin, M. Tetrahedron Lett. 1986, 27, 2283.

126.Peterson, E. M.; Xu, K.; Holland, K. D.; McKeon, A. C.; Rothman, S. M.; Ferrendelli, J. A.; Covey, D. F. J. Med. Chem. 1994, 37, 275.

127.Caussanel, F.; Wang, K.; Ramachandran, A.; Deslongchamps, P. J. Org. Chem. 2006, 71, 7370.

128.Bouyssi, D.; Monteiro, N.; Balme, G. Tetrahedron Lett. 1999, 40, 1297.

129.Flynn, D. L.; Becker, D. P.; Nosal, R.; Zabrowski, D. L. Tetrahedron Lett. 1992, 33, 7283.

130.Andersson, P. G.; Backvall, J.- E. J. Org. Chem. 1991, 56, 5349.

131.Mori, K.; Murata, N. Liebigs Ann. Chem. 1994, 637.

132.Nzita, L.; Ladame S.; Gomez, L.; Moreau, S. Nucleosides Nucleotides 1997, 16, 1781.

133.Leeper, F. J.; Rock, M. J. Fluorine Chem. 1991, 51, 381.

134.Evans, P. A.; Kennedy, L. J. J. Am. Chem. Soc. 2001, 123, 1234.

135.Oswald, M. F.; Parsons, A. F.; Yang, W.; Bowden, M. Tetrahedron Lett. 2005, 46, 8087.

136. Soucy, P.; Dory, Y. L.; Deslongchamps, P. Bull Soc. Chim. Fr. 1994, 131, 271.

137.Dory, Y. L.; Ouellet, C.; Berthiaume, S.; Favre, A.; Deslongchamps, P. Bull. Soc. Chim. Fr. 1994, 131, 121.

138. Ndibwami, A.; Lamothe, S.; Guay, D.; Plante, R.; Soucy, P.; Goldstein, S.; Deslongchamps, P. Can. J. Chem. 1993, 71, 695.

139.Fox, H. H.; Wolf, M. O.; O’Dell, R. Lin, B. L.; Schrock, R. R.; Wrighton, M. S. J. Am. Chem. Soc. 1994, 116, 2827.

140.(a) Deslongchamps, P.; Lamothe, S.; Lin, H.-S. Can. J. Chem. 1984, 62, 2395. (b) Deslongchamps, P.; Lamothe, S.; Lin, H.-S. Can. J. Chem. 1987, 65, 1298.

141.Stolle, A.; Becker, H.; Salaun, J.; de Meijere, A. Tetrahedron Lett. 1994, 35, 3517.

142.Lampe, J. W.; Hanna, R. G.; Piscitelli, T. A.; Chou, Y.-L.; Erhardt, P. W.; Lumma, W. C. Jr.; Greenberg, S. S.; Ingebretsen, W. R.; Marshall, D. C.; Wiggins, J. J. Med. Chem. 1990, $33,1688$.

143.Chen, L.; Dovalsantos, E.; Yu, J.; Lee, (K.S) S; O’Neill-Slawecki; Mitchell, M.; Sakata, S.; Borer, B. Org. Process Res. Dev. 2006, 10, 838.

144. Ayad, H. M.; Wheeler, T. N. J. Agric. Food. Chem. 1984, 32, 85.

145.Hattori, K.; Grossman, R. B. J. Org. Chem. 2003 68, 1409. 
146.(a) Manhas, M. S.; Banik, B. K.; Mathur, A.; Vincent, J. E. Bose, A. K. Tetrahedron 2000, 56, 5587. (b) Banik, B. K.; Manhas, M. S.; Newaz, S. N.; Bose, A. K. Bioorg. Med. Chem. 1993, 3, 2363. (c) Banik, B. K.; Manhas, M. S.; Robb, E. W.; Bose, A. J. Heterocycles 1997, 44, 405.

147.Qian, X.; Zheng, B.; Burke, B.; Saindane, M. T.; Kronenthal, D. R. J. Org. Chem. 2002, 67, 3595.

148.Bari, S. S.; Sharma, A. K.; Sethi, M. K. Indian J. Chem. 1998, 37B, 1114.

149.Simig, G.; Fetter, J.; Hornyak, G.; Zauer, K.; Doleschall, G.; Lempert, K.; Nyitrai, J.; Gombos, Z.; Gizur, T.; Barta-Szalai, G.; Kajtar-Peredy, M. Acta Chim. Hung. 1985, 119, 17.

150.(a) Fetter, J.; Lempert, K.; Kajtar-Peredy, M.; Simig, G.; Hornyak, G.; Horvath, Z. J. Chem. Res. (S) 1985, 368.; J. Chem. Res. (M) 1985, 3901. (b) Simig, G.; Doleschall, G.; Hornyak, G.; Fetter, J.; Lempert, K.; Nyitrai, J.; Huszthy, P.; Gizur, T.; Kajtar-Peredy, M. Tetrahedron 1985, 41, 479. (c) Greff, Z.; Horvath, Z.; Nyitrai, J.; Kajtar-Peredy, M.; Brlik, J. J. Chem. Res. (S) 1990,170: J. Chem. Res. (M) 1990, 1201.

151.Futamura, Y.; Kurokawa, M; Obata, R.; Nishiyama, S.; Sugai, T. Biosci. Biotechnol. Biochem. 2005, 69, 1892.

152.Caron, M; Kawamata, T.; Ruest, L.; Soucy, P.; Deslongchamps, P. Can. J. Chem. 1986, 64, 1781.

153. Ndibwami, A.; Deslongchamps, P. Can. J. Chem. 1986, 64, 1788.

154.(a)Lange, K.; Schneider, M. P. Tetrahedron: Asymmetry 2004, 15, 2811.(b) Melnick, M; Reich, S. H.; Lewis, K. K.; Mitchell, L. J., Jr.; Nguyen, D.; Trippe, A. J.; Dawson, H.; Davies, J. F. II; Appelt, K.; Wu, B.-W.; Musik, L.; Gehlhaar, D. K.; Webber, S.; Shetty, B.; Kosa, M.; Kahil, D.; Andrada, D. J, Med. Chem. 1996, 39, 2795.

155.Pohlhaus, P. D.; Johnson, J. J. J. Am. Chem. Soc. 2005, 127, 16014.

156.Blum, Z.; Ekstrom, M.; Wistrand, L.-G. Acta Chem. Scandinavica 1984, 38B, 297.

157.Funaki, I.; Thijs, L.; Zwanenburg, B. Tetrahedron 1996, 52, 9909.

158. Nagy, T.; Jeannin, L.; Sapi, J.; Laronze, J. Y.; Renard, P.; Pfeiffer, B.; Bizot-Espiard, J. G. Eur. J. Med. Chem. 1995, 30, 575.

159. Wilt, J. W. Tetrahedron 1985, 41, 3979.

160. Schill, G.; Priester, C. U.; Windhovel, U. F.; Fritz, H. Tetrahedron 1987, 43, 3765.

161.Settimj, G.; Del Giudice, M. R.; Ferretti, R.; Gatta, F. J. Heterocyclic Chem. 1988, 25, 1391.

162.Danishefsky, S. J.; Harrison, P. J.; Webb, R. R. II; O’Neill, B. T. J. Am. Chem. Soc. 1985, 107, 1421.

163.Fetter, J.; Kajtar-Peredy, M.; Keskeny, E.; Lempert, K. Acta Chim. Hungarica-Models in Chemistry 1993, 130, 683.

164. Mellor, J. M.; Pathirana, R. N. J. Chem. Soc. Perkin Trans. 1 1984, 761.

165.Galons, H.; Labidalle, S.; Mioque, M.; Ligniere, B.; Bram, G. Phosphorus and Sulfur 1988, 39, 73.

166.Leanna, M. R.; Morton, H. E. Tetrahedron Lett. 1993, 34, 4485.

167.Kinsho, T.; Mori, K. Agric. Biol. Chem. 1989, 53, 2785. 
168.Crisp, G. T.; Glink, P. T. Tetrahedron Lett. 1992, 33, 4649.

169.Doelling, K.; Krug, A.; Hartung, H.; Weichmann, H. Z. Anorg. Allg. Chem. 1995, 621, 63.

170.Bernard, A. M.; Piras, P. P. Synth. Commun. 1997, 27, 709.

171.(a) Bremner, J. B.; Coates, J. A.; Keller, P. A.; Pyne, S. G.; Witchard, H. M. Tetrahedron 2003, 59, 8741. (b) Bremner, J. B.; Coates, J. A.; Keller, P. A.; Pyne, S. G.; Witchard, H. M. Synlett 2002, 219.

172.Huth, A.; Schmiechen, R.; Motoc, I.; Beetz, I.; Breitkopf, A.; Frost, E.; Schumann, I.; Thielert, K. Arch Pharm. (Weinheim) 1988, 321, 297.

173.Redman, J. E.; Ghadiri, M. R. Org. Lett. 2002, 4, 4467.

174.Nielsen, B.; Fisker, H.; Ebert, B.; Madsen, U.; Curtis, D. R. ; Krogsgaard-Larsen, P.; Hansen, J. J. Bioorg. Med. Chem. Lett. 1993, 3, 107.

175.Loupy, A.; Petit, A.; Zaparucha, H.; Mahieu, C.; Semeria, D. Bull. Soc. Chim. Fr. 1994, 131, 642.

176.DeGraw, J. I.; Christie, P. H.; Brown, E. G.; Kelly, L. F.; Kisliuk, R. L.; Gaumont, Y.; Sirotnak, F. M. J. Med. Chem. 1984, 27, 376.

177.DeGraw, J. I.; Tagawa, H.; Christie, P. H.; Lawson, J. A.; Brown, E. G.; Kisliuk, R. L.; Gaumont, Y. J. Heterocyclic Chem. 1986, 23, 1.

178. Choubal, M. D.; Fernandez, E. J.; Crumrine, D. S.; Pavkovic, S. F. Acta Cryst. 1992, C48, 1501 .

179. (a) Purrington, S. T.; Everett, T. S.; Bumgardner, C. L. Tetrahedron Lett. 1984, 25, 1329. (b)

Everett, T. S.; Purrington, S.T.; Bumgardner, C. L. J. Org. Chem., 1984, 49, 3702.

180.Brillon, D. Synth. Commun. 1986, 16, 291.

181.Park, O. S.; Kim, H. J.; Chae, W. K.; Lee, W. Y. Bull. Korean Chem. Soc. 1993, 14, 639.

182.Cheeseman, E. N. Org. Prep. Proc. Int. 1990, 22, 519.

183.Harnden, M. R.; Jarvest, R. L. J. Chem. Soc. Perkin Trans. 1 1988, 2777.

184.Fritz, H.; Soleymani-Jamarani, M.; Bats, J. W.; Teuber, H.-J. Liebigs Ann. Chem. 1993, 705.

185.Battersby, A. R.; Westwood, S. W. J. Chem. Soc. Perkin Trans. 1 1987, 1679.

186.Barta, N. S.; Kirk, B. A.; Stille, J. R. J. Am. Chem.. Soc. 1994, 116, 8912.

187.Randad, R. S.; Kulkarni, G. H. Synth. Commun. 1985, 15, 311.

188.Blanchard, A. N.; Burnell, D. J. Tetrahedron Lett. 2001, 42, 4779.

189. Mori, K.; Kuwahara, S.; Fujiwhara, M. Proc. Indian Acad. Sci. (Chem. Sci.) 1988, 100, 113

190.Berube, G.; Deslongchamps, P. Can. J. Chem. 1990, 68, 404.

191. Trost, B. M.; McClory, A. Org. Lett. 2006, 8, 3627.

192.Lerm, M.: Gais, H.-J.; Cheng, K.; Vermeeren, C. J. Am. Chem. Soc. 2003, 125, 9653.

193. Vares, L.; Koulov, A. V.; Smith, B. D. J. Org. Chem. 2003, 68, 10073.

194.Ramana. C. V.; Rajender Reddy, K.; Nagarajian, M. Indian J. Chem. 1996, 35B, 534.

195.Atkinson, R. S.; Grimshire, M. J. J. Chem. Soc. Perkin Trans. 1 1987, 1135.

196.Knerr, L.; Schmidt, R. R. Synlett 1999, 1802. 
197.Moriggi, J.-D.; Brown, L. J.; Castro, J. L.; Brown, R. C. D. Org. Biomol. Chem. 2004, 2, 835.

198.Jeyaraj, D. A.; Kapoor, K. K.; Yadav, V. K.; Gauniyal, H. M.; Parvez, M. J. Org. Chem. 1998, 63, 287.

199.Okada, M.; Sumitomo, H.; Sassa, T.; Takai, M.; Hall, H. K. Jr.; Bruck, M. Macromolecules 1990, 23, 2427.

200.Leonardi, A.; Nava, G.; Nardi, D. Il Farmaco ( Sci.Edit), 1983, 38, 290.

201.(a) Carvalho, C. F.; Sargent, M. V. J. Chem. Soc. Perkin Trans. 1 1984, 1605. (b) Sargent, M. V.; Stransky, P. O. J. Chem. Soc. Perkin Trans. 1 1982, 2373.

202.Ishihara, J.; Nonaka, R.; Terasawa, Y.; Tadano, K.-I.; Ogawa, S. Tetrahedron:Asymmetry 1994, 5, 2217.

203.Tadano, K.I.; Murata, T.; Kumagi, T.; Isshiki, Y.; Ogawa, S. J. Carbohydrate Chem. 1993, 12, 1187.

204.Tanikaga, R.; Miyashita, K.; Ono, N.; Kaji, A. Synthesis 1982, 131.

205.Ono, N.; Tamura, R.; Eto, H.; Hamamoto, I.; Nakatsuka, T.; Hayami, J.-I.; Kaji, A. J. Org. Chem. 1983, 48, 3678

206.Nishide, K.; Kobori, T.; Tunemoto, D.; Kondo, K. Heterocycles 1987, 26, 633.

207.Knolker, H.-J.; Hitzemann, R. Tetrahedron Lett. 1994, 35, 2157.

208.(a) Bernard, A. M.; Cerioni, G.; Piras, P. P., Tetrahedron 1990, 46, 3929. (b) Bernard, A. M.; Piras, P. P.; Serra, A., Tetrahedron Lett.1985, 26, 4391.

\section{Author}

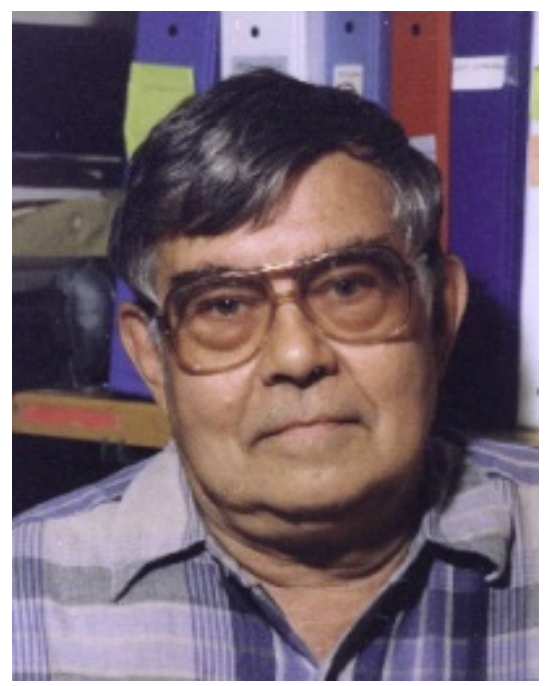

A. Paul Krapcho was born in Alden Station, PA on March 6, 1932. He did his undergraduate work at Penn State (B.S. in Chemistry, 1953) and graduate studies at Harvard University (Ph.D. 1957). He then spent the 2-year period of 1957-1959 teaching at Smith College and then held a 
post-doctoral position at Penn State from 1959-1960 (with Phil Skell). In 1960 he joined the faculty at the University of Vermont, where he is currently an Emeritus Professor of Chemistry still active in research. He has directed the research of numerous undergraduate and graduate students in projects related to natural product synthesis, solvolytic studies of spiro analogues, reaction mechanism studies of metal-ammonia reductions, chemistry of carbenes (or carbenoids), reactions of $\alpha$-anions of acids and esters, and the preparation of anticancer heterocyclic analogues. Krapcho has been a Fulbright scholar at the University of Montpellier, France (19681969), a research scholar at Stanford University (1976-1977) and an invited lecturer at Addis Ababa University in Ethiopia (1981). He was a research scholar at Duke University (1983-1984), the University research scholar in Physical Sciences (1990), a visiting Professor at the University of Auckland Medical School in Auckland, New Zealand (Spring 1991) and, for a short period, at Humboldt University in Berlin, Germany (1998). He has been involved over the past 15 years in a collaborative anticancer drug development program initially with the Vermont Cancer Center, and then with Novuspharma SpA of Milan, Italy (recently merged with CTI) and the University of Padova, Padova, Italy. These projects deal with the synthesis of telomerase inhibitors. Recently (2005-present) he was awarded a Dreyfus Senior Scientist Mentor grant. Krapcho is a Scientific Editor for ARKIVOC (2000-present) and a Co-Editor-in-Chief of Mini-Reviews in Medicinal Chemistry (2001-present). 